\title{
GRADIENT ANALYSIS AND CLASSIFICATION OF CAROLINA BAY VEGETATION: A FRAMEWORK FOR BAY WETLANDS CONSERVATION AND RESTORATION
}

\author{
by \\ Diane De Steven', Ph.D., and Maureen Toner ${ }^{2}$, Ph.D. \\ 'Department of Biological Sciences \\ University of Wisconsin-Milwaukee \\ Milwaukee WI 53201 \\ for \\ U.S.D.A. Forest Service \\ Savannah River Forest Station \\ P.O. Box 710 \\ New Ellenton, South Carolina 29802
}

October 1997

2 Present address: Forest Management Branch, Departmènt of Natural Resources and Energy Fredericton, New Brunswick E3B 5H1, Canada 
TABLE OF CONTENTS (section and page number)

Introduction (1)

Landscape Setting (3)

Savannah River Site

Regional

Methods for Bay Studies (9)

Bay selection

Vegetation sampling

Ordination analysis of vegetation

Environmental measures

Bay history

Community classification

Results and Discussion (13)

Gradient analysis of vegetation (13)

Classification of bay communities (21)

Plant species richness in bay communities

Environmental and landscape correlates of vegetation types

Landscape correlates of environmental drivers (27)

Vegetation dynamics and succession (31)

Historical patterns of vegetation change

Model of vegetation dynamics

Conservation strategies and implications for bay vegetation restoration (38)

\section{LIST OF TABLES (page)}

Table 1. Spearman rank correlations between principal environmental variables and ordination scores for SRS Carolina bays (15)

Table 2. Spearman rank correlations between principal environmental variables and ordination scores for Upper Coastal Plain Carolina bays (19)

Table 3. Principal features of bay community-types identified by cluster analysis (25)

Table 4. Regional landscape distribution of Carolina bay community-types (26)

Table 5. Characteristics of Carolina bays across different soil/landform areas (29)

Table 6. Transitions between 1951 bay cover types and present-day vegetation types (32)

Table 7. Life history traits and environmental tolerances of significant species (37)

Table 8. Environmental templates for vegetation in bays (38) 


\section{LIST OF FIGURES}

Fig. 1. Soil/landform areas on the Savannah River Site, based on a generalized soil classification (4)

Fig. 2. Generalized map of soil/landform areas on the Upper Coastal Plain of NW South Carolina (7)

Fig. 3. Joint plot of DCA ordination for 35 Carolina bays on the SRS (14)

Fig. 4a. Joint plot of DCA ordination for 57 Carolina bays in the Upper Coastal Plain of NW South Carolina (18)

Fig. 4b. DCA ordination of Figure 4a, showing location of bays either on the SRS or in the surrounding region (20)

Fig. 5. Dendrogram for Carolina bays of the Upper Coastal Plain of NW Carolina, derived from UPGMA clustering using Sorenson's distance (23)

Fig. 6. Site-type based community succession model for Upper Coastal Plain Carolina bays (35)

\section{LIST OF APPENDICES}

App. A. Summary features of Carolina bays used in the survey

App. B. Characterization of Carolina bay hydrology

App. C. Characterization of Carolina bay soils

App. D. Relevant environmental and historic variables for 57 Carolina bays in the study

App. E. Endangered, threatened, and sensitive species identified in the survey bays

App. F. Sample information provided to cooperating private landowners and managers 


\section{ACKNOWLEDGMENTS}

Many people assisted in the expansion of this study in 1995 and 1996. We thank Mary Ford and Amanda Garris for able help in the field, and the staff and members of the Savannah River Forest Station and the Savannah River Ecology Lab's Wetlands Division for extensive logistical support. Hydrology data provided by Robert Lide were essential to the study. Special thanks to Robert Eppinette (Natural Resource Conservation Service) for the field soil surveys, and to Dale Soblo (SC Nature Conservancy), Stephen Bennett and Albert Pittman (SC Heritage Trust Program), and staff of the NRCS field offices in Allendale and Bamberg Counties for help in locating and gaining access to study sites on private and state lands. At the SC Land Resouces Division in Columbia, Bobbie Adams and Jeff Brantley provided generous access to aerial photography and maps, and Richard Scharf supplied advice on South Carolina soils; they all made the map room on Devine Street a great place to work. We also thank John Nelson of the University of South Carolina's Moore Herbarium for helpful assistance. Finally, we gratefully acknowledge the landowners and land managers who gave us permission to survey the Carolina bays on their properties. This research was supported by USFS Cooperative Research Agreement No. 29-1280 between the Southern Forest Station (J. Walker, Designated Station Rep.) and the University of Wisconsin-Milwaukee); thanks to John Blake, Savannah River Forest Station, for supporting and facilitating this agreement. 


\section{INTRODUCTION}

In the southeastern Coastal Plain, "depression-wetlands" (Carolina bays and similar features) are a habitat complex of regional concern for biodiversity conservation. Their vegetation is diverse, they may contain regionally rare plant species, and they provide critical habitat within a terrestrial landscape matrix for animal species such as amphibians, aquatic reptiles, and birds (see Richardson \& Gibbons 1993). Historically, these wetlands formed part of the natural heterogeneity of the upland landscape and were subject to natural disturbance processes such as periodic wildfire and drought. However, since European settlement, many bays have experienced severe alteration or complete destruction from land uses such as timber removal, fire suppression, and ditching and draining. The mineral-soil bays of the Upper Coastal Plain (non-peat or "hard-bottom" bays; cf. Bennett \& Nelson 1991) were especially impacted, because the surrounding uplands had soils favorable for agriculture and such bays could be drained relatively easily. A recent survey for South Carolina indicated that intact Carolina bay communities were much rarer than previously believed, and that destructive losses are ongoing (Bennett \& Nelson 1991).

In the Upper Coastal Plain landscape, the extensive land area of the US Dept. of Energy Savannah River Site (SRS) in South Carolina provides a significant opportunity for conservation and restoration of Carolina bay habitats. Roughly 200 intact bays and/or wetland depression features have been identified on the SRS (Schalles et al. 1989, Lide 1994), which is located at the margin of the geographic region of greatest bay density. In the context of the US-DOE Cooperative Biological Diversity Research Program (US DOE-SRS 1993), Carolina bays were identified as a 'special-interest' habitat for the SRS in relation to multiple objectives of: 1) restoration of community-types of regional concern and conservation of endangered, threatened, and key species, 2) identification of landscape patterns and processes that influence biodiversity, and 3) compensatory mitigation of wetland impacts (cf. US DOE-SRO 1993). In addition to ongoing activities of conserving and managing intact Carolina bays (e.g. in the SRS Set-Aside Areas), restoration of anthropogenically-disturbed bays is anticipated for mitigation banking purposes.

The bays in the SRS landscape are distinctive in having been largely protected from major disturbances since the SRS was established in 1950-51. As a consequence, their plant composition reflects nearly 50 years of post-disturbance succession and thus may represent seral stages and potential vegetation for a variety of sites. The SRS setting provides both a pool of candidate bays for protection or restoration and also an unusual opportunity to identify important patterns and processes for their plant communities.

To provide a framework for conserving and restoring Carolina bay habitats, it is important to: 1) identify the range of existing and potential vegetation types in relation to structuring environmental factors such as landform, soils, basin size, and hydrology, and 2) determine how potential vegetation and dynamics have been altered by past disturbance and landuse. A preliminary study in 1993 (De Steven 1994) suggested that vegetation diversity in Carolina bays was correlated with site hydrologic, soil, and landscape factors, but more detailed analysis with wider sampling and more accurate hydrologic data were needed 
to verify these patterns. Thus in 1995-96, we expanded the survey of bay vegetation both on the SRS and in the surrounding region of the western Upper Coastal Plain of South Carolina. Through explicit analysis within a landscape context, we sought to identify patterns of community diversity and the environmental correlates of those patterns.

This report addresses four project objectives:

1. Gradient model of Carolina bay vegetation on the SRS: We use ordination analyses to identify environmental and landscape factors that are correlated with vegetation composition. Significant factors can provide a framework for site-based conservation of existing diversity, and they may also be useful site predictors for potential vegetation in bay restorations.

2. Regional analysis of Carolina bay vegetation diversity: We expand the ordination analyses to assess the degree to which SRS bays encompass the range of vegetation diversity found in the regional landscape of South Carolina's western Upper Coastal Plain. Such comparisons can indicate floristic status relative to regional potentials and identify missing species or community elements that might be re-introduced or restored.

3. Classification of vegetation communities in Upper Coastal Plain bays: We use cluster analysis to identify plant community-types at the regional scale, and explore how this classification may be functional with respect to significant environmental and landscape factors. An environmentally-based classification at the whole-bay level can provide a system of "templates" for managing bays as individual units and for restoring bays to desired plant communities.

4. Qualitative model for bay vegetation dynamics: We analyze present-day vegetation in relation to historic land uses and disturbances. The distinctive history of SRS bays provides the possibility of assessing pathways of post-disturbance succession. We attempt to develop a coarse-scale model of vegetation shifts in response to changing site factors; such qualitative models can provide a basis for suggesting management interventions that may be needed to maintain desired vegetation in protected or restored bays. 


\section{LANDSCAPE SETTING}

To characterize the diversity of Carolina bays in relation to the physical environment, we first identified the range of soil and landform areas both on the SRS and in the regional landscape of the Upper Coastal Plain of NW South Carolina. Where possible, soil regions were correlated with surficial geology (Nystrom et al. 1986, Prowell 1994).

\section{Savannah River Site.}

Carolina bays and bay-like wetland depressions occur in 3 areas (Fig. 1):

- "Sandhills" uplands: areas of deep sands on the northern and eastern perimeters of the SRS, and also outcropping in the southeast and along the lower reaches of Upper Three Runs Creek. These soils are associated with an Early Pliocene 'Dune Sand' surficial geologic unit and with exposures of the Eocene Barnwell group (Tobacco Road Sand, Dry Branch Formation). Many of the larger and most distinct Carolina bays on the SRS are found in the Dune Sand areas of the Lower Three Runs and Salkehatchie watersheds.

- "Coastal Plain" uplands: areas of shallow sands with sandy clay loam subsoils. These soils are associated with a widespread Miocene (?) surficial geologic unit (variously termed the 'Upland' unit, Hawthorn Formation, or Citronelle Formation), which caps interfluvial ridges and consists of complex interbedded sands, clays, and gravels. These Coastal Plain uplands have abundant Carolina bay features (historically also termed 'Grady ponds' or 'high ponds').

- Coastal Plain "terrace": low-lying areas with clayey soils and soils that are frequently saturated; deeper sandy soils also occur locally. The terrace is a Quaternary alluvial plain adjacent to the present-day Savannah River floodplain. Bay-like depressions occur frequently on the terrace, although they do not always display the distinctive shape and orientation of 'classic' Carolina bays. 


\section{FIGURE 1.}

Soil/landform areas on the Savannah River Site, based on a generalized soil classification. Map was prepared using a GIS coverage with data at the scale of soil map-units (from Rogers 1990). Map-unit polygons were aggregated based on soil physical properties and taxonomy (USDA system). Points $(\bullet)$ show the locations of 35 Carolina bay wetlands surveyed in 1993 and 1995.

Legend for soil/landform areas :

Fluvial : river floodplain soils and similar soils in upland depressions and drainageways

Deep sands : "Sandhills" soils -- upland soils with 'grossarenic' profiles (i.e. sandy to depths $>48$ ")

Shallow sands : "Coastal Plain" soils -- upland soils with 'typic' or 'arenic' profiles (i.e. sandy to depths of $24-48$ " over sandy clay loam subsoils )

Clayey (terrace) : soils with clay or sandy clay subsoils; found on the low-lying alluvial Terrace landform and classified in 'aquic' soil subgroups

Saturated (terrace) : soils in the 'Aquult' suborder; found on the Terrace landform and also in bays and other wetlands 


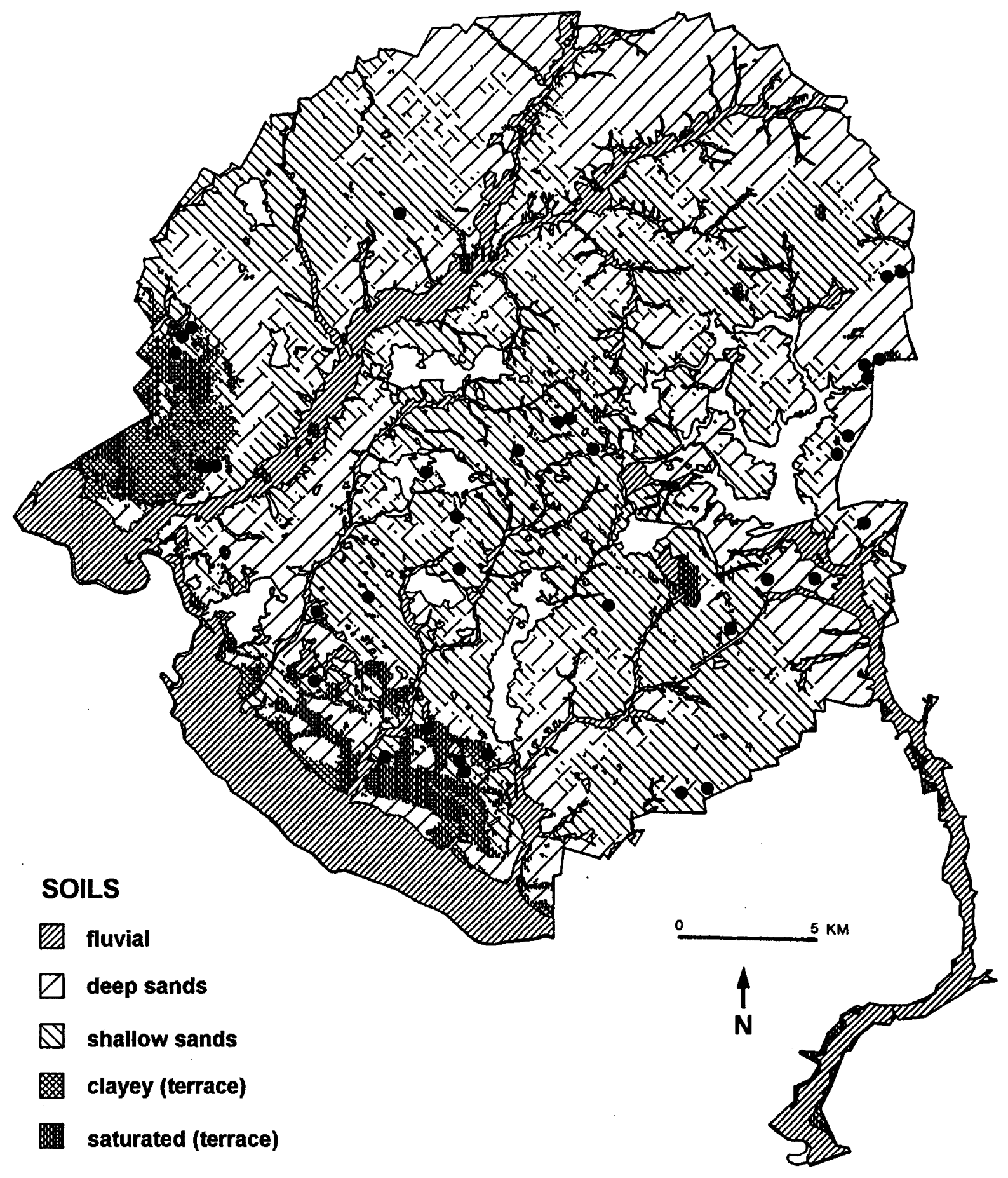




\section{Regional.}

A regional assessment was developed for the 9-county area that encompasses South Carolina's western Upper Coastal Plain above the Orangeburg scarp. Because a much larger land area was considered, soils were generalized at a coarser scale of county soil associations. Although correlation between soil associations and specific soil map units is not precise, nonetheless it was possible to identify soil/landform areas comparable to those on the SRS (Fig. 2):

- "Sandhills" uplands (deep sands)

- “Coastal Plain” uplands (shallow sands)

- "Terrace"

At the regional landscape scale, a new soil grouping was identified, consisting of Coastal Plains upland soils with clay subsoils (Marlboro, Faceville, and Varina series) (clayey associations in Fig. 2). On the SRS, this soil grouping has negligible extent in the uplands and so was not recognized in mapping. A notable feature of the regional landscape is a disjunct area of Coastal Plain soils adjacent to the Piedmont in Edgefield and Saluda Counties; this area (the "peach ridge") has many Carolina bay or 'high pond' features, although most have been destroyed by agricultural land use.

Correlations of regional soils groupings with surficial geologic units are similar to those for the SRS. Apart from discrepancies between soil survey designations and surficial geology for NW Allendale Co., "Sandhills" appear associated with the Dune Sand unit (and perhaps the Barnwell Group units), both "Coastal Plain" areas ('shallow sands' and 'clayey') are found on the Upland unit, and "Terraces" are on Quaternary alluvium. Although NW Allendale Co. has been generalized as "Sandhills" in the county soil survey, the soils here are on the Upland geologic unit but resemble the soils of the Middle Coastal Plain (Atlantic Coast Flatwoods region). 


\section{FIGURE 2.}

Generalized map of soil/landform areas on the Upper Coastal Plain of NW South Carolina, encompassing the 9-county area of Aiken, Allendale, Bamberg, Barnwell, Calhoun, Edgefield, Lexington, Orangeburg, and Saluda Counties. Map was prepared from a GIS coverage of the STATSGO database (Natural Resource Conservation Service 1994), with data at the scale of county soil associations $(1: 250,000)$. Soil-association polygons were aggregated based on soil physical properties and taxonomy of the predominant soils in each association. Generalization was based on original county soil surveys and may not reflect recent revisions of a SC general soils map. Points $(\bullet)$ show the locations of 22 Carolina bay wetlands surveyed in 1996.

\section{Legend for soil/landform regions :}

Deep sands : soil associations of the Sandhills uplands; generally very sandy to sandy soils ( 'grossarenic' and 'arenic' soil subgroups )

Shallow sands : soil associations of Coastal Plain uplands; soils with sand or loamy sand over sandy clay loam subsoils ('typic' and 'arenic' soil subgroups )

Clayey : soil associations of Coastal Plain uplands which have significant extents of clayey soils ( 'clayey, kaolinitic' soil family )

Terrace : soil associations on Coastal Plain terraces adjacent to present-day floodplains of large rivers; soils of 'aquic' subgroups and/or the 'Aquult' suborder

Valley/Fluvial : soil associations of steep valleys, river floodplains, and drainageways

Middle C.P. : soil associations of the middle Coastal Plain physiographic region, below the Orangeburg Scarp (also referred to as the Atlantic Coast Flatwoods region)

Piedmont : soil associations of the Piedmont physiographic region 

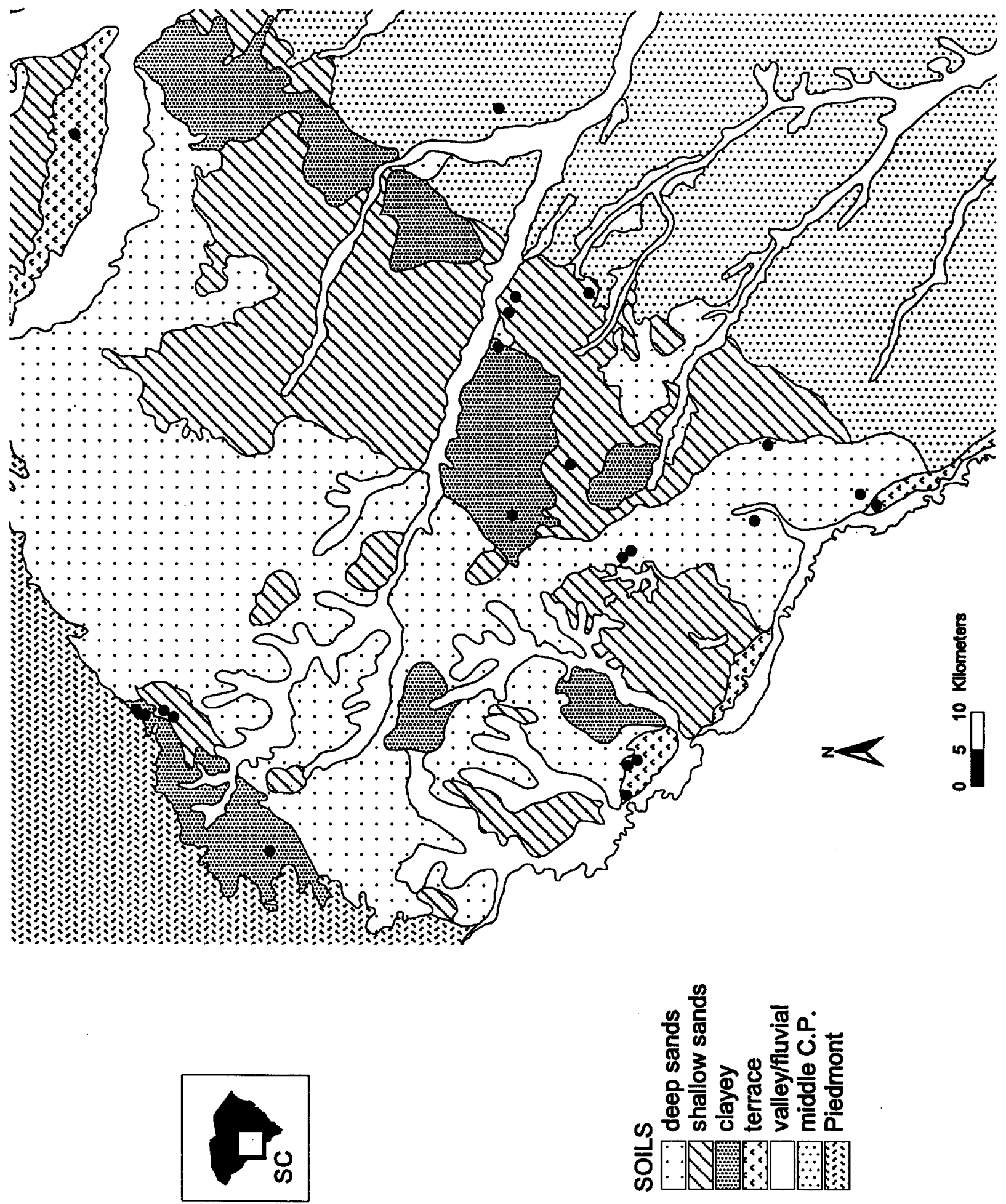


\section{METHODS FOR BAY STUDIES}

\section{Bay selection}

Savannah River Site. From among the ca. 200 bay-like wetlands mapped on the SRS (Schalles et al. 1989), we selected bays from an initial random subset of 88 sites for which there were coarse-scale hydrologic data (from DeBiase \& Taylor of SREL). To adequately represent landscape-level variation, a few bays not in the subset of 88 were also selected. Based on aerial photography (1992 CIR, 1:15,840), bay selection was refined by excluding sites that were not true depression wetlands (e.g. stream head-water embayments) or that had been destroyed by recent land management activities. The resulting sample of 35 bays (App. A) was a representative group that was stratified across the 3 soil/landform areas (cf. Fig. 1) and that spanned the typical size range of SRS bays (median size $=3 \mathrm{ha}$; range $=0.4-12 \mathrm{ha}$ ).

Regional. To develop a representative sample of reasonably intact Carolina bays, one to several aerial photos (1994 NAPP CIR; 1:40,000) within each major soil association in each of the 9 counties were examined for the presence of potentially suitable sites. Parts of some counties (e.g. sandhills areas of Aiken, Lexington, Orangeburg, and Calhoun Cos.) lacked significant bay features. Based on a subset of photos which had potential sites and which represented as much as possible the regional soils areas, bays were selected in a haphazard process that partly depended upon the availability of land ownership information and the ability to obtain landowner permission to conduct field surveys. The size range was restricted to be comparable to the SRS bay sample (i.e. very large bays were not selected), but we otherwise attempted to avoid bias as to type of vegetation sampled. Public agencies and NGO's (SC Heritage Trust, USDA NRCS, and The Nature Conservancy) aided in locating sites where access was feasible. The resulting sample of 22 bays (App. A) was reasonably well-stratified across the major landscape regions (cf. Fig. 2) and had a comparable size range to SRS bays (median size $=3$ ha; range $=1-20 \mathrm{ha}$ ). With TNC's cooperation, we included in the sample one 'terrace' bay in Richland County and a 'Middle Coastal Plain' bay located below the Orangeburg Scarp in Orangeburg Co. Both bays appear associated with a Late Pliocene surficial geologic unit (Prowell 1994, Maybin \& Nystrom 1995).

\section{Vegetation sampling}

The goal of vegetation sampling was to characterize the predominant plant species composition of the bay as a single community (management unit). We used a methodology that permitted rapid assessment of many bays, but the trade-off was a method which was not effective for enumerating total plant diversity or for detecting rare species.

We sampled bay vegetation with a line-intercept method consisting of 3 linear transects: one across the bay long axis and two transverse axes crossing the long axis at $1 / 3$ and $2 / 3$, respectively, of its length. (Porcher 1966 used a similar transect array). Transects began and ended at the bay 'edge', defined as points located beyond winter high-water marks and on any 
topographic rise suggesting a basin rim. Plant species presence was recorded in vertical projections of $1-\mathrm{m}$ line segments spaced every $10 \mathrm{~m}$ along each transect. Ground-layer, midstory, and canopy-layer species were recorded separately, with all shrubs assigned to the ground layer. Any species seen near the transects but not falling within the sample segments was recorded as a single 'incidental' occurrence in that bay. This design provided sampling intensity that increases proportionally with bay size, thus species percent frequency over all sample segments is proportionate to that species' relative coverage in the bay. The design thus gave a realistic assessment of overall vegetation composition across the entire bay.

On the SRS, 27 bays were sampled in 1993 and 8 in $1995(n=35)$ ( 2 additional bays that had been sampled were omitted because they were later determined to be headwater embayments). For 5 of the SRS bays (\#64,66,67,78, 83), vegetation data were collected by Keough et al. in 1993 (cf. Keough et al. 1989). They also used a line-intercept sampling method but a different design; however, we subsampled their datasets in a manner that approximated our 3-transect study design. Keough et al. did not systematically record 'incidental' species, thus species richness for these 5 bays may be slightly under-estimated relative to other bays. All bays outside of the SRS were sampled in $1996(n=22)$. Optimal sampling time was from mid-July through August to detect plant species of both early- and late-summer phenologies.

\section{Ordination analysis of vegetation}

For each bay, we calculated species percent frequency based on all sample segments located $\geq 20 \mathrm{~m}$ from the bay edge in each transect. Plots at $0 \mathrm{~m}$ (bay edge) and at $10 \mathrm{~m}$ distance were omitted to reduce the effect of species transitional to the uplands and thus to increase confidence in representing the true 'interior' vegetation. A species occurring in multiple strata within a single sample segment (e.g. in both mid-story and canopy) was recorded as one occurrence for that segment. 'Incidental' species were arbitrarily assigned a low frequency of $0.2 \%$. Because of the proportional sampling design, percent frequency gives a meaningful estimate of species relative abundance within each bay.

Ordination analysis was performed on the species frequencies using a combination of Detrended Correspondence Analysis (DCA) and Non-metric Multi-Dimensional Scaling (NMDS), accompanied by progressive fragmentation of the dataset (cf. Peet \& Christensen 1980). Plant species occurring in only one bay in the SRS dataset ( $n=35$ bays), or in only two bays in the combined regional dataset ( $n=57$ bays), were deleted from the data matrices before performing the ordinations. Where appropriate, some species taxa were also combined at the generic level. . Removal of single occurrences provided robust, input order-invariant DCA results, particularly for the first ordination axis: random 'shuffles' of the data matrices yielded no change in the rank order of ordination scores (contrary to Tausch et al. 1995). DCA was performed using CANOCO Ver. 3.12 (Ter Braak 1988, 1990) with all program defaults. PCORD Ver. 2.0 (McCune and Mefford 1995) was used for NMDS, with initial scores derived from Bray-Curtis ordination (variance-regression method, data relativized by sample; cf. Beals 1984). 
Ordinations were run separately on SRS bays and on the combined regional set of all bays (i.e. on and outside SRS). Generally 1-2 ordination axes were interpreted. DCA and NMDS gave very similar results; however, DCA provided a clearer initial characterization of variation among bays for each dataset, whereas NMDS provided better resolution of environmental correlations for data subsets after fragmenting. Based on stress analysis, 3-dimensional NMDS solutions were calculated; the second axes generally did not reveal substantial new pattern, but the third axes served to reduce the impact of site outliers. Spearman rank correlations were used to test relationships between ordination scores and environmental measures.

\section{Environmental measures}

For correlation with the ordinations, we used the following measures for the major environmental factors that could influence bay vegetation patterns:

- bay hydrology: For SRS bays, the best indicator of bay hydrology was the C.V. of mean seaonal water depth, based on staff gage measurements collected in 1995 (wet year) and 1996 (dry year). C.V. is an inverse index of hydroperiod: smaller values indicate more stable water depths through the season and thus longer flooding duration. For bays in the combined regional dataset (all bays), we used a derived hydroperiod index to provide a relative ranking of estimated flooding duration in 1996, where $1=$ longest flooding duration and $4=$ shortest duration. See App. B for details of hydrology analyses.

- bay soils: Soil types of each bay's interior were determined by R. Eppinette, NRCS, based on field descriptions of standard 60-in. soil profile cores. We used the depth of sand over a 'clayey' layer (i.e. 'clay' or 'sandy clay' texture) as a quantitative measure of soil type. If a soil profile had no clay or sandy clay layer throughout its depth, then sand depth was assigned a value of 60 in. Sand depth was averaged over 1-4 profiles for each bay. From the central soil cores in each SRS bay, subsamples at 0-6 in. (topsoil), 24-30 in. (shallow subsoil), and 56-60 in. (deep subsoil) were collected for soil chemistry analysis. For the off-SRS bays, only topsoil and shallow subsoil subsamples were collected, because preliminary data indicated that shallow and deep subsoils were similar in chemical composition. For each subsample in each bay, particle-size distribution, soil $\mathbf{p H}$ and concentrations of soil macronutrients (total $\mathrm{N}, \mathrm{P}, \mathrm{K}, \mathrm{Ca}, \mathrm{Mg}$ ) were determined by the Soil and Plant Analysis Lab, Univ. of Georgia. See App. C for details.

- bay size: Two-dimensional area of each bay was obtained from digitized imagery (for SRS: Lide 1994 GIS coverage of a SPOT image; for off-SRS bays: planimeter measurements from SCS soil survey manual photos). Because digitized areas correlated strongly with the lengths of the long-axis field transects (Spearman $\mathrm{r}_{\mathrm{s}}=0.83 ; n=57$; $\mathrm{P}<0.001$ ), we used long-axis length as a more accurate measure of relative bay size.

- landscape: Each bay was characterized by the soil/landform area in which it occurred, i.e. Sandhills uplands, Coastal Plain uplands (both shallow-sand and clayey associations), or Terrace. 


\section{Bay history}

Bays on the SRS are distinctive in the regional landscape in having the potential for ca. 45 years of post-disturbance succession after Site acquisition in 1950-51. Aerial photographs for the year 1951 (SCS B\&W 1:20,000) were interpreted for the following variables that could indicate the history of past disturbances and surrounding landuses, as well as vegetation changes in the bays from 1951 to the present:

- bay interior vegetation : percentage of interior that was either open, sparsely-treed, or forested $($ total $=100 \%)$

- bay disturbance index : degree of alteration of the bay perimeter (as an indicator of past disturbance) scored as: $0=$ no evident disturbance, $1=$ one minor impact (e.g. small ditch or path), $2=$ one major impact (e.g. large ditch or road-sized break), $3=\geq 2$ major impacts, $4=$ intrusion of surrounding landuse into the bay interior

- index of ditching impact : scored as $0=$ no ditches, $1=$ ditch on perimeter, $2=$ ditch through bay interior

- bay perimeter : percentage of bay perimeter with trees

- landuse : percentage of a 100-m buffer zone around the bay perimeter that was either open (generally agricultural), sparsely-treed (e.g. oldfields), or forested. We also scored for the presence of wetland or bottomland forest within this 100-m buffer zone.

- burning history : years (prior to 1996) since the most recent rough-reduction burn in the forest compartment or half-compartment where each bay was located, scored as: $1=<4$ yr, $2=4-8 \mathrm{yr}$, and $3=\geq 9 \mathrm{yr}$. Detailed fire records do not exist for the bays, and fire history reconstuction from sediment analysis, etc. was beyond the scope of this study.

Bays outside of the SRS were not necessarily protected and may be subject to ongoing disturbance. However, we attempted to sample those that appeared to be functional wetlands or that likely had similar successional status to SRS bays. As for the SRS, we used historical aerial photographs to interpret the same variables (except fire history, for which no information was available). Because there was no complete set of photos for a single baseline year, interpretations were based on a series spanning the years 1951-1958, with a few as late as 1963 . More recent photography was examined to note the timing of any further impacts or changes in landuse to the present. Landowner comments were also helpful in some instances.

\section{Community classification}

For the regional sample of 57 bays, we used UPGMA cluster analysis ( $\underline{\text { Unweighted }}$ Pair Group Method, Average-linkage) of the species frequency data to produce a classification of community-types at the whole-bay level, based on the predominant interior vegetation. Cluster analysis was performed in PC-ORD, using Sorenson's distance measure. 


\section{RESULTS AND DISCUSSION}

\section{Gradient analysis of vegetation}

\section{Savannah River Site}

DCA ordination revealed a pattern of highly-variable vegetation composition among the 35 SRS bays (Fig. 3). Axis 1 length was 4.6 s.d. and Axis 2 length nearly 4.0 s.d.; values $\geq 4$ suggest that samples at axis extremes are completely dissimilar (or nearly so). Axis 1 identified a structural vegetation gradient from non-forested to forested bays, as shown by significant positive correlation with a 'vegetation index' measuring the percent of sample line segments in a bay having canopy and/or mid-story strata (Table 1). The ordination pattern was strongly weighted by a small number of abundant species that tended to dominate in different bays, particularly the aquatic macrophyte Nymphaea odorata, the grasses Panicum hemitomon and Leersia hexandra, and the trees Nussa biflora var. biflora, and Liquidambar styraciflua.

Environmental measures were related in complex ways to both DCA axes (Table 1):

- hydrology: The hydrologic measure C.V. was positively correlated with first axis in 1995 only, whereas it was negatively correlated with the second axis in both 1995 and 1996. C.V. has low values if flooding duration is long and high values if flooding duration is short (cf. App. B); thus hydroperiod is decreasing across Axis 1 and increasing across Axis 2. Dataset fragmentation (see below) showed this result to be a consequence of distinct hydrologies exhibited in bays dominated by Leersia, bays dominated by Liquidambar, and the remaining bays.

- soils: Across the first DCA axis, bay soil type changed significantly from sandy soils to clayey soils, as reflected in decreasing sand depth (cf. Fig. 3). Concentrations of topsoil $\mathrm{N}, \mathrm{Ca}$, and $\mathrm{Mg}$ were positively correlated with the second DCA axis. The correlations suggest a tendency for organic matter accumulation in bays with longer hydroperiods (i.e. those dominated by Nymphaea, Panicum, or Nyssa), because clayey soils as a group did not have significantly higher topsoil nutrient levels than sandy soils, and because total $\mathrm{N}$ reflects soil organic matter content (cf. App. C). No other soil chemistry was significantly related to ordination pattern in any analyses.

- bay size: Size, as measured by long-axis length, showed only a weak positive correlation with the second DCA axis. This reflects a tendency for bays dominated by Nymphaea to be among the larger bays on the SRS, though not exclusively so.

- landscape: Ordination provided only a weak separation of bays with respect to soil/landform area. Bays in the Coastal Plain uplands tended to array to the right on the first DCA axis and were dominated by Liquidambar and/or Acer rubrum. On the second axis, bays of the Sandhills uplands showed some displacement from the Terrace bays.

- burning history: The coarse-scale available data did not reveal any suggestive pattern relating vegetation to the potential for fire at the compartment or half-compartment scale. 


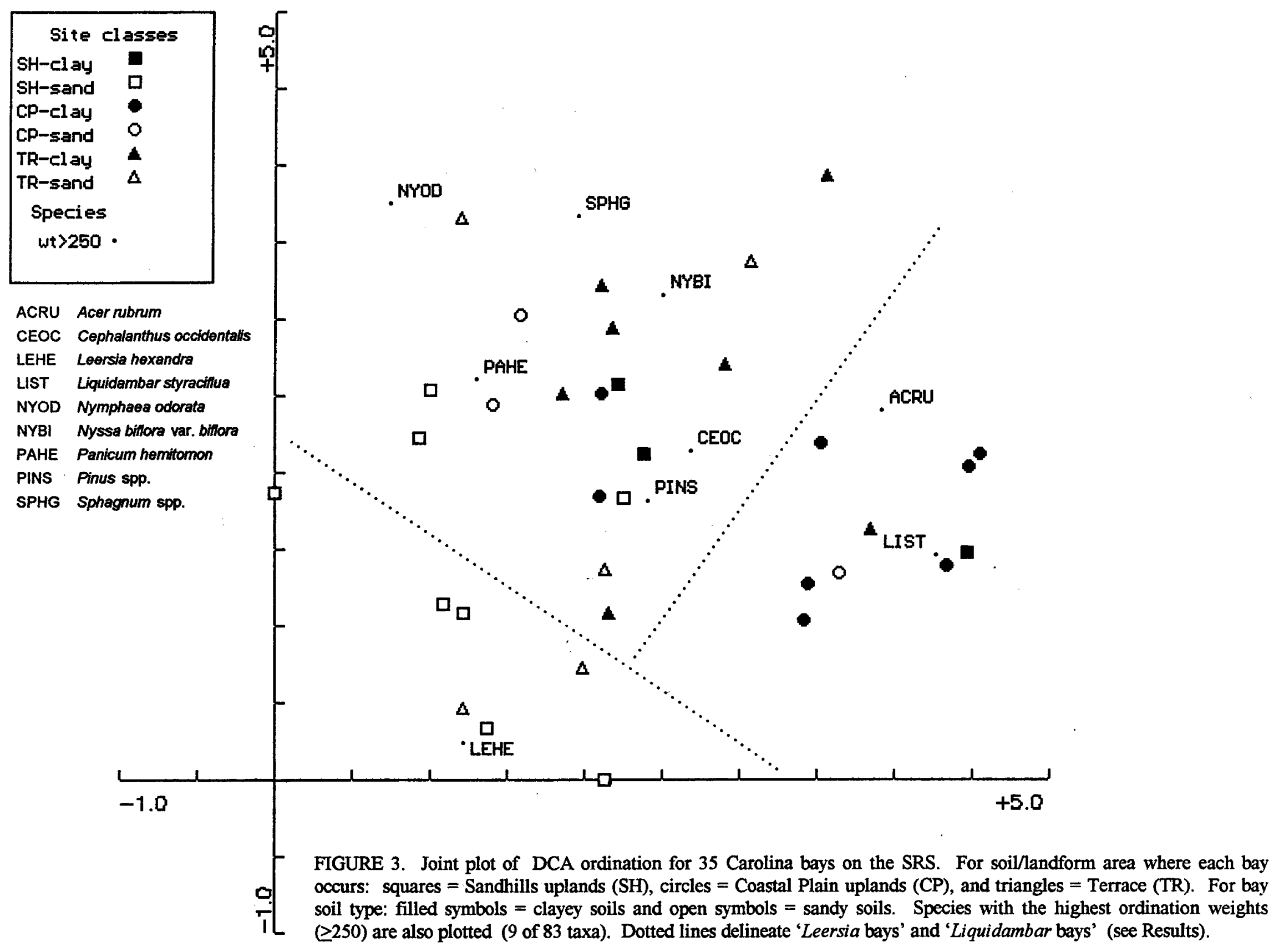


TABLE 1. Spearman rank correlations between principal environmental variables and ordination scores for SRS Carolina bays. DCA was performed on all bays $(n=35)$; for DCA, $\lambda$ is the axis eigenvalue and $\mathrm{L}$ is the axis length in s.d. units. NMDS was used for two different fragmentations of the dataset: Fragmentation $1=$ 'Leersia bays' omitted $(n=27)$ and Fragmentation $2=$ 'Liquidambar bays' omitted ( $n=25$ ). An outlier bay (\#79) was also excluded from the NMDS analyses. One axis of each NMDS ordination was interpreted.

\begin{tabular}{|c|c|c|c|c|}
\hline \multirow[b]{2}{*}{ Variable } & \multicolumn{2}{|c|}{ All bays } & \multirow{2}{*}{$\begin{array}{l}\text { Fragmentation } 1 \\
\text { NMDS Axis } 1 \\
\end{array}$} & \multirow{2}{*}{$\begin{array}{l}\text { Fragmentation } 2 \\
\text { NMDS Axis } 1 \\
\end{array}$} \\
\hline & DCA Axis 1 & DCA Axis 2 & & \\
\hline & $\lambda=0.62$ & $\lambda=0.49$ & - & - \\
\hline & $\mathrm{L}=4.6$ & $\mathrm{~L}=3.9$ & - & - \\
\hline \multicolumn{5}{|l|}{ Hydrologic measure: } \\
\hline C.V. of depth, 1995 (wet year) & $0.44 * *$ & $-0.52 * *$ & $0.55 * *$ & -0.19 \\
\hline C.V. of depth, 1996 (dry year) & 0.28 & $-0.64 * *$ & $0.52 * *$ & $-0.53 * *$ \\
\hline \multicolumn{5}{|l|}{ Soil features: } \\
\hline sand depth over a clayey subsoil & $-0.58 * *$ & -0.19 & $-0.50 * *$ & $-0.44 *$ \\
\hline topsoil $\mathrm{N}$ & -0.03 & $0.43 *$ & -0.26 & $0.55 * *$ \\
\hline topsoil $\mathrm{Ca}$ & 0.12 & $0.45 * *$ & -0.11 & $0.46 *$ \\
\hline topsoil Mg & 0.07 & $0.49 * *$ & -0.11 & $0.41 *$ \\
\hline \multicolumn{5}{|l|}{ Size index: } \\
\hline bay length & -0.26 & $0.38 *$ & -0.31 & 0.12 \\
\hline \multicolumn{5}{|l|}{ Vegetation index: } \\
\hline$\%$ canopy/midstory coverage & $0.78 * *$ & 0.04 & $0.71 * *$ & $0.47 *$ \\
\hline
\end{tabular}


To resolve the complex DCA pattern, we used cluster analysis (see below) to assist the delineation of 2 dissimilar groups at the axis extremes: open bays with high abundance of Leersia and forested bays dominated by Liquidambar (cf. Fig. 3). We then performed NMDS ordination on 2 subsets ('fragmentations') of the 35-bay dataset: one with 7 'Leersia bays' omitted and one with 9 'Liquidambar bays' omitted. The ordination array of the bays in each subset did not change appreciably from the DCA pattern; therefore NMDS results can be interpreted from Fig. 3. In each analysis, one axis was sufficient to identify significant environmental factors (Table 1):

- Fragmentation 1: Without the Leersia bays, NMDS axis 1 replicated the non-forest to forest gradient, and it distinguished the Liquidambar bays as having clayey soils (i.e. significant decrease in sand depth) and typically short hydroperiods (i.e. high C.V. both in the wet year of 1995 and the dry year of 1996). Nutrient chemistry was not significant for this NMDS axis.

- Fragmentation 2: Without the Liquidambar bays, NMDS axis 1 replicated DCA axis 2, and it corroborated the distinction between Leersia bays and the remaining bays dominated by Nymphaea, Panicum, and/or Nyssa. Leersia bays dried down in 1996 but not in 1995, thus C.V. was significantly correlated with the NMDS axis only in 1996. The remaining bays maintained stable flooding levels in both years. Leersia bays had sandier soils than the remaining bays as a group (negative correlation of sand depth). Topsoil N, Ca, and Mg correlated positively with this NMDS axis, again supporting the association between higher nutrient levels (organic matter accumulation) and bays with long hydroperiods. Weak significance of the 'vegetation index' indicated the Leersia bays to have less woody canopy coverage than the remaining bays as a group. 
Regional

DCA ordination of the regional dataset (SRS and off-SRS bays) produced a vegetation pattern that was basically identical to that for the SRS bays alone (Fig. 4a; note the 'mirror image' reversal across axis 2). Along with the important species identified in the SRS ordination, other significant dominants were revealed at the regional scale, specifically cypress (Taxodium ascendens and possibly $T$. distichum) and Carex walteriana, a robust sedge. Neither had occurred in the SRS dataset with sufficient frequency to indicate their importance.

Environmental correlations with vegetation were generally confirmed at the regional scale, but some relationships were less distinct (Table 2):

- hydrology: As for the SRS ordination, the 1996 hydroperiod index was positively correlated with both the first and second DCA axes. The index resembles C.V. in having low values if flooding duration is long and high values if flooding duration is short (cf. App. B); thus hydroperiod decreases both across Axis 1 (reflecting short hydroperiods in Liquidambar bays) and also across Axis 2 (reflecting the shorter 1996 hydroperiods of Leersia bays). NMDS analyses on fragmented datasets confirmed these hydrologic patterns.

- soils: As for the SRS ordination, sand depth decreased significantly across the first DCA axis, which indicates a trend toward predominantly clayey soils in the Liquidambar bays. However, relationships to soil types were not significant upon dataset fragmentation. This was the consquence of 4 bays that arrayed with the Leersia group but that had clayey soils instead of the sandy soils found in all other Leersia bays. Three of these 4 clay-soil bays are located in the disjunct Coastal Plain uplands of Saluda and Aiken Counties near the town of Monetta. We suspect that local landscape factors such as ground-water inputs (J. Holman, pers. comm.) could be influencing these bays and making them unlike other bays of Coastal Plain uplands.

- bay size: Similar to the trend for the SRS, negative correlation of bay length with the first DCA axis and positive correlation with the second DCA axis more strongly confirmed that bays dominated by Nymphaea tend to be larger than other bays. NMDS ordinations corroborated these size patterns.

- landscape: The weak patterns identified for the SRS were similar at the regional landscape scale. Liquidambar bays were associated with the clayey soils of the Coastal Plain uplands, and there was some differentiation in composition of Sandhills bays and Terrace bays across the second DCA axis.

A notable result was that ordination analysis showed no distinct separation of SRS bays from bays in the surrounding region (Fig 4b). This suggests that the SRS generally encompasses the range of floristic diversity that occurs in this part of the South Carolina Upper Coastal Plain. Given the highly-diverse vegetation among bays, and the degree to which a limited number of species tended to dominate in different bays, we used cluster analysis (see below) to classify bays into discrete community-types (identified for each bay in Fig. 4b). 


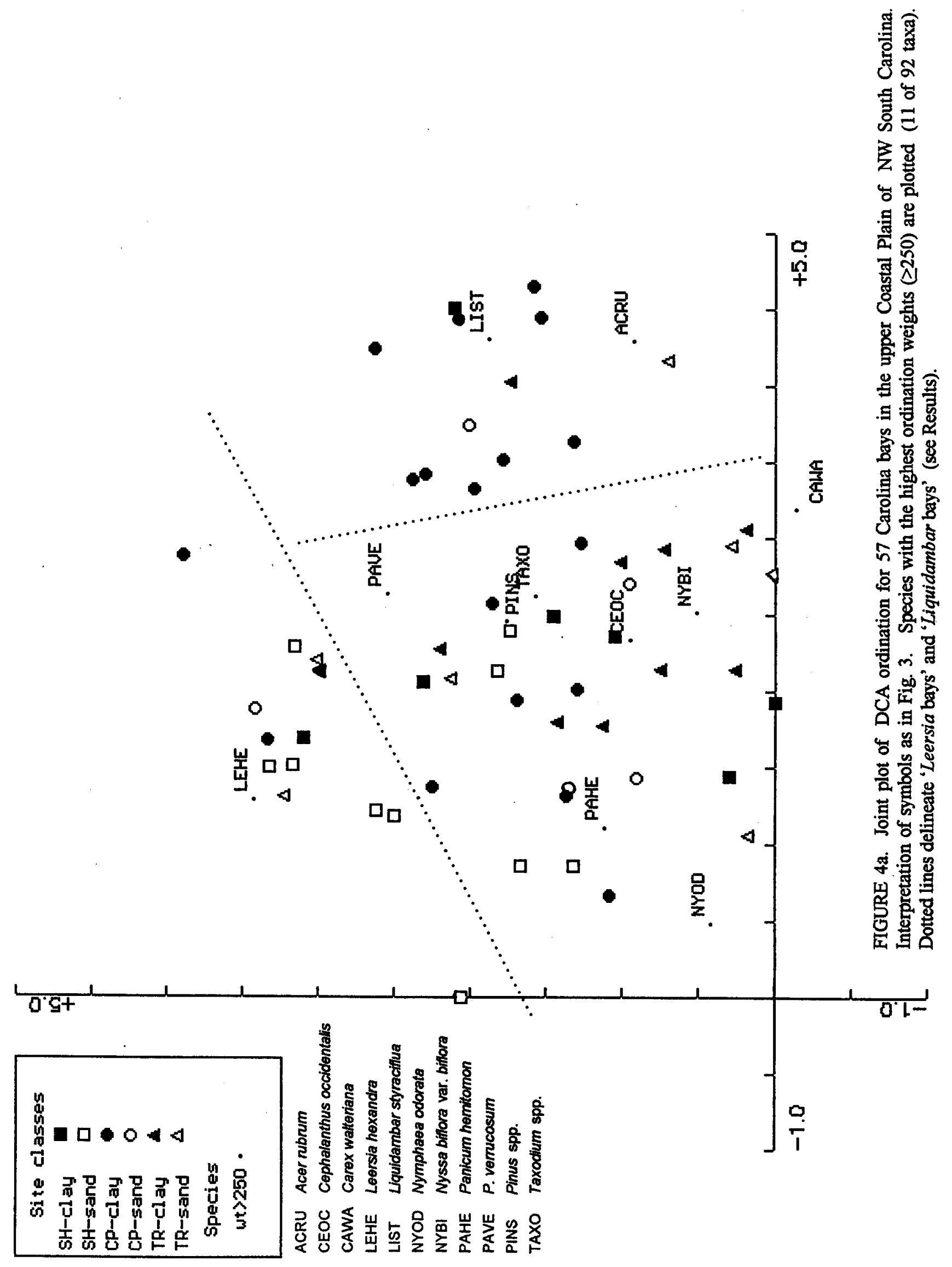


TABLE 2. Spearman rank correlations between principal environmental variables and ordination scores for Upper Coastal Plain Carolina bays. DCA was performed on all bays $(n=57)$, with one outlier site ( $\# 680)$ entered passively. NMDS was used for two different dataset fragmentations: $1=$ 'Leersia bays' omitted $(n=44)$ and $2=$ 'Liquidambar bays' omitted $(n=44)$. In Fragmentation 2 , Axis 2 was the relevant axis for environmental correlation. Other interpretation as for Table 1.

\begin{tabular}{|c|c|c|c|c|}
\hline \multirow[b]{2}{*}{ Variable } & \multicolumn{2}{|c|}{ All bays } & \multirow{2}{*}{$\begin{array}{l}\text { Fragmentation } 1 \\
\text { NMDS Axis } 1 \\
\end{array}$} & \multirow{2}{*}{$\begin{array}{l}\text { Fragmentation } 2 \\
\text { NMDS Axis } 2 \\
\end{array}$} \\
\hline & DCA Axis 1 & DCA Axis 2 & & \\
\hline & $\lambda=0.58$ & $\lambda=0.50$ & - & - \\
\hline & $L=4.6$ & $L=3.9$ & - & - \\
\hline Hydroperiod index (1996) : & $0.36 * *$ & $0.38 * *$ & $0.58 * *$ & $0.51 * *$ \\
\hline \multicolumn{5}{|l|}{ Soil features: } \\
\hline sand depth over a clayey subsoil & $-0.34 * *$ & -0.09 & -0.22 & 0.18 \\
\hline topsoil N & -0.21 & $-0.36 * *$ & $-0.41 * *$ & $-0.49 * *$ \\
\hline topsoil Ca & -0.14 & -0.09 & $-0.30 *$ & -0.15 \\
\hline topsoil Mg & -0.07 & -0.08 & -0.19 & -0.12 \\
\hline \multicolumn{5}{|l|}{ Size index: } \\
\hline bay length & $-0.29 *$ & $-0.35 *$ & $-0.44 * *$ & $-0.32 *$ \\
\hline \multicolumn{5}{|l|}{ Vegetation index: } \\
\hline$\%$ canopy/midstory coverage & $0.78 * *$ & -0.24 & $0.77 * *$ & $-0.44^{*}$ \\
\hline
\end{tabular}

$* \mathrm{P} \leq 0.05 ; * * \mathrm{P} \leq 0.01 ; * * * \mathrm{P} \leq 0.001$ 


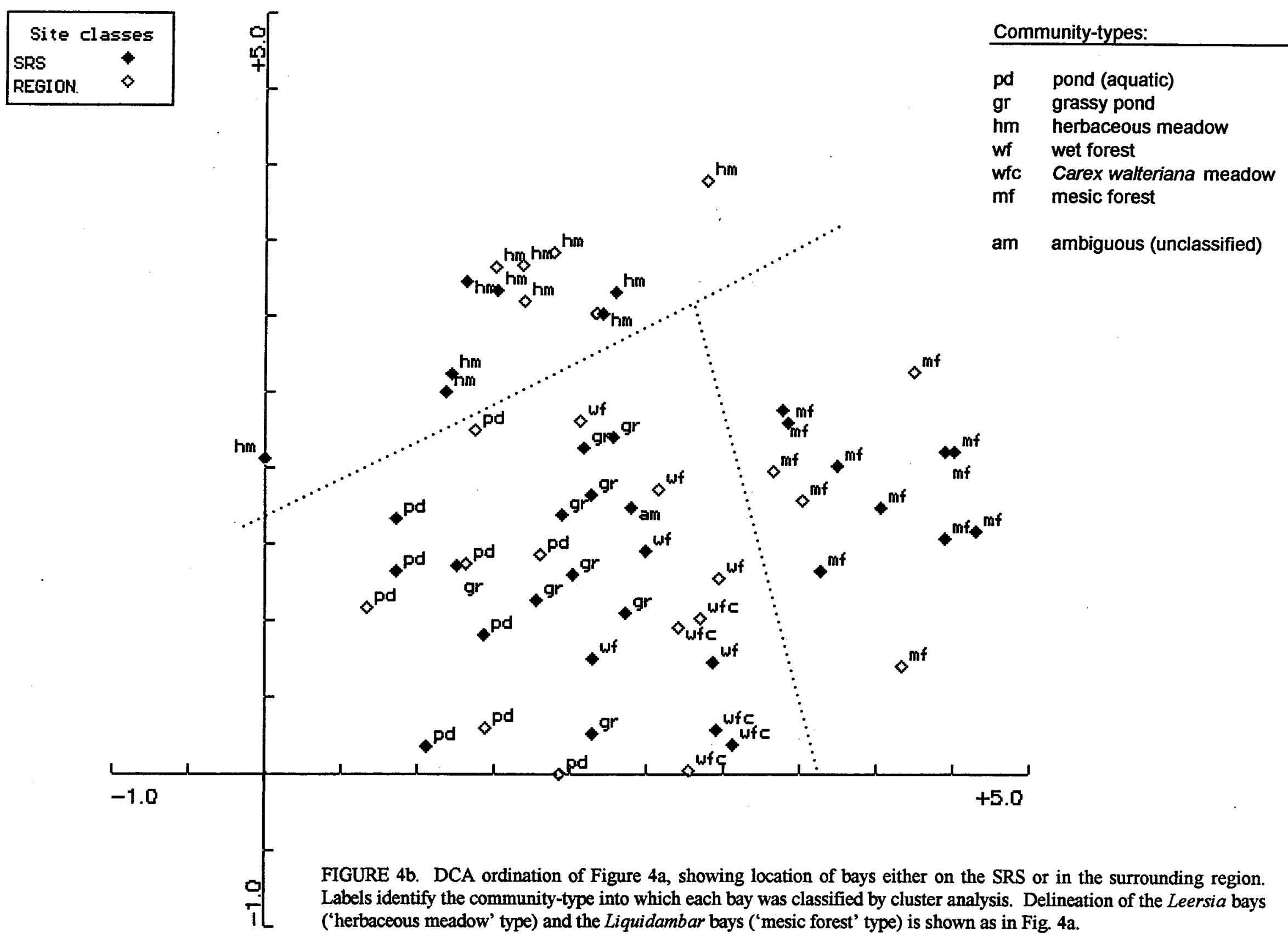




\section{Classification of bay communities}

Cluster analysis of the regional dataset (Fig. 5) identified a set of loose groups which we have generalized as 6 community-types: 1) aquatic pond, 2) grassy pond, 3) herbaceous meadow, 4) "wet" forest, 5) Carex walteriana meadow, and 6) "mesic" forest. Each type is characterized by a dominant, diagnostic species as well as by associated species which had high constancy or relative abundance in the group (Table 3). All 6 types were evident, or at least suggested, at the level of the SRS data. Two ("herbaceous meadow" and "mesic forest") were distinct in the ordination analyses (Fig. 4b), whereas the other four were not wellseparated and may represent a series of interrelated transitional types that are loosely structured by hydrologic variation (and perhaps by history). Most groups correspond to community-types suggested in Bennett \& Nelson's (1991) state-wide survey of Carolina bays.

- Aquatic pond. Diagnostic species: water lily, Nymphaea odorata (average freq. $=58 \%$ ). Aquatic ponds correspond to Bennett \& Nelson's "open water lake" type; they are deepwater bays $(\geq 1 \mathrm{~m})$ dominated by floating-leaved macrophytes (Nymphaea, Brasenia schreberi, Nelumbo lutea). Large, deep bays may have aquatic vegetation centrally, surrounded by peripheral bands of Panicum hemitomon, herbaceous meadow species, and/or swamp tupelo (Nyssa sylvatica var. biflora). This is the classical zonation pattern (cf. Richardson and Gibbons 1993) that has been mistakenly assumed for all Carolina bays.

- Grassy pond. Diagnostic species: maidencane, Panicum hemitomon (average freq. $=57 \%$ ). Ordination analysis shows Panicum-dominated bays to intergrade with most other types (except mesic forest) to varying degrees. There is no equivalent community in Bennett \& Nelson's system, nor was this type identified outside of the SRS. Panicum bays may be a shallower variant of aquatic ponds and/or transitional to wet forest.

- Herbaceous meadow. Diagnostic species: cutgrass, Leersia hexandra (average freq. = 46\%). This community type corresponds Bennett \& Nelson's "depression meadow", described as uncommon in South Carolina and restricted largely to the state's western Upper Coastal Plain. Its meadow-like character derives from dominance by the non-robust cutgrass and from the frequent presence of spike-rushes (Eleocharis), herbaceous forbs (Ludwigia, Rhexia) and other sedges and grasses that develop after water draw-downs. Tree species are minor components with the exception of pines (Pinus taeda, P. elliottii), which appear to display cycles of invasion and dieback during and following drought episodes. This open community is highly-valued because of the associated presence of many rare plant speces (e.g. Coreopsis rosea, Rhexia aristosa, Sagittaria isoetiformes).

- Wet forest. Diagnostic species: swamp tupelo, Nyssa sylvatica var. biflora (average freq. = $63 \%$ ). This closed-canopy type corresponds to Bennett \& Nelson's "non-alluvial swamp" and is distinguished by the 'obligate wetland' trees (indicator status, sensu Reed 1988) swamp tupelo and/or cypress (Taxodium). Bennett \& Nelson identified cypress-dominated bays as a distinct community-type, but selective logging of cypress from many bays makes it difficult to determine what factors may distinguish cypress bays from those with swamp tupelo. In our analyses, bays with significant Taxodium coverage were not clearly distinct floristically from Nyssa bays. 
- Carex walteriana meadow. Diagnostic species: Walter's sedge, $C$. walteriana (average freq. $=71 \%$ ). Bays dominated by this robust sedge are a distinctive community that was not recognized by Bennett \& Nelson; however, stands of $C$. walteriana were found as a zonal type in Maryland bays (Tyndall et al. 1990). These bays often have peripheral zones of swamp tupleo and thus may be transitional to wet forest. One bay in this group might be classed as Bennett \& Nelson's 'pond cypress savannah' type (cf. App. A) based on the associated presence of Taxodium; this bay was located on the Middle Coastal Plain and was particularly species-rich. It is possible that pond-cypress savannah is an element of a different community-complex more typical of the Outer (i.e. Middle and Lower) Coastal Plain.

- Mesic forest. Diagnostic species: sweetgum, Liquidambar styraciflua (average freq. = 67\%). Mesic forest bays represent the "regrowth" type of Bennett \& Nelson and were the most distinctive community type in our survey. In contrast to "wet forest" bays, mesic forest bays are dominated by 'facultative' or 'facultative wetland' species (indicator status sensu Reed 1988) and resemble some types of floodplain forest. The closed canopy is comprised of Liquidambar, Acer rubrum, and/or Ulmus spp., with 'facultative' woody vines (Campsis radicans, Smilax) as common elements. Wetter central areas may have a shrub cover of Cephalanthus occidentalis or scattered wet-forest trees (Nyssa).

\section{Plant species richness in bay communities.}

Across the regional sample of 57 bays, a total of approximately $\mathbf{3 0 0}$ species was identified from the field sampling. However, the average number of species per bay was 22 ( \pm 1 s.e.; range 7-57) and did not differ significantly among community-types (cf. Table 3). Because sampling effort was generally comparable (proportional) across all bays, these results reinforce the finding of strong species dominance in these communities. Some of the discrepancy between the regional species total and species richness per bay reflects chance sampling variation, because a complete species inventory of each bay was not possible with the survey method used. The analysis also de-emphasized the presence of species in the transitional bay edge, but a similar pattern of species richness was found in a previous bay survey that incorporated these transitional zones (De Steven 1994). Nonetheless, given that bay environments are differentiated with respect to hydrology, soils, and history, it appears that a significant degree of vegetation diversity is expressed at a regional scale (i.e. among-bays) as well as at a local scale (i.e. within-bay).

Although detection of rare plant species was not a project objective, more than a dozen threatened or sensitive species were found in the field surveys (listed in App. E). Few species were unique to bays outside the SRS; thus the range of site types that support them would appear to be available on or adjacent to the SRS. Nearly all were found in the open community-types, principally aquatic ponds, herbaceous meadows, and Carex meadows. 
FIGURE 5. Dendrogram for Carolina bays of the Upper Coastal Plain of NW South Carolina, derived by UPGMA clustering using Sorenson's distance. Community-types are assigned as: pd: aquatic pond; gr: grassy pond; hm: herbaccous meadow; wf: wet forest; cw: Carex walteriana meadow; mf: mesic forest; am: ambiguous. Two outliers $(\# 680,682)$ were assigned as ' $h m$ ' based on ordination results.

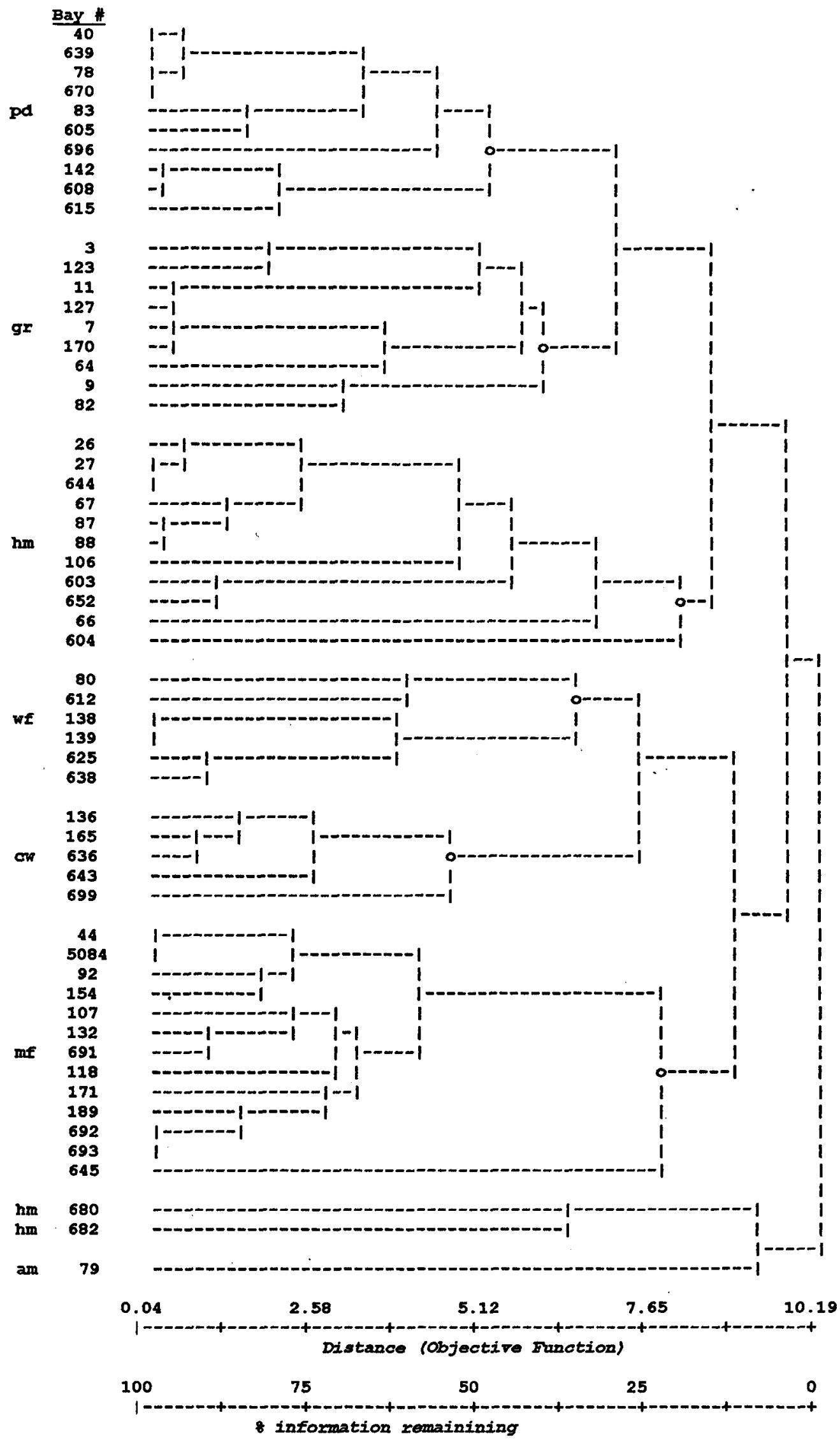


Environmental and landscape correlates of vegetation types. Environmental factors identified as important by ordination analysis were confirmed as differing among community-types (Table 3), and some types were associated with particular landscape areas (Table 4):

- Aquatic pond: These bays were significantly larger than bays of other types, and they are characterized by deep and continuous flooding throughout the year. Soils are variable, but tend to be clayey (median sand depth $=18$ in).

- Grassy pond: These bays are somewhat smaller than aquatic ponds and are characterized by shallow flooding for most or all of the year. Soil types resemble those of aquatic ponds (median sand depth $=14$ in).

- Herbaceous meadow: These bays exhibited variable hydrology, remaining flooded during the wet year of 1995 but drying down during the dry year of 1996. They were distinctive in having very sandy soils (mean sand depth $=35$ in), with the exception of a few sites in the disjunct Coastal Plain uplands of Saluda/Aiken Counties. Topsoil organic matter content (reflected in $\% \mathrm{~N}$ ) was also low. On the SRS, herbaceous-meadow bays were associated with the "Sandhills" area of the Lower Three Runs and Salkahatchie River watersheds, and also occurred on sandy soils of the Terrace landform. Given these locations, intermittent groundwater inputs may also influence the distribution of this type.

- Wet forest and Carex walteriana meadow: Bays of both types are characterized by shallow flooding throughout most or all of the year. Both types were associated with lower topographic elevation and thus may have significant groundwater inputs; in particular, Carex bays were found either on river terraces or, in one case, on the Middle Coastal Plain below the Orangeburg scarp. Bays with these two communities are of similar size, although Carex bays tend to be slightly larger. Soils may differentiate the two types: the closed-forest bays have clayey soils (mean sand depth $=11$ in) whereas at least some Carex bays have sandier soils (mean sand depth $=28$ in).

- Mesic forest: These bays have typically short hydoperiods, generally drying down by late May or early June each year and, in many respects, resembling floodplain forests that are only seasonally-flooded. The mesic forest type was found predominantly on Coastal Plain soils of the Upland geologic unit and thus are likely to receive surface water inputs only. Similar to "wet" forest bays, mesic forest bays almost exclusively have clayey soils. These bays also had the highest indices of past disturbance; in the 1951 photography, most had open cover and signs of ditching or other major impacts.

Any classification is necessarily an approximation. The predominant vegetation in some bays may be transitional to other communities. Within a bay there may be zonal vegetation from peripheral mesic species to central hydric species, which reflects short-distance gradients in water depth and also historical multi-year fluctuations of water level. Nonetheless, the high dominance of particular species groups suggests that there are recognizable communities with some relative "stability" under particular hydrologic and substrate conditions. Thus these community-types could provide a useful system of 'potential vegetation' for the conservation and restoration of individual bays as management units. 
TABLE 3. Principal features of bay community-types identified by cluster analysis. Quantitative data are means and s.e. (in parenthesis); high values are noted in boldface and low values are underlined. Differences among types are tested by non-parametric Kruskal-Wallis or $\chi^{2}$ statistics (except area, which was tested by ANOVA). ${ }^{+} 0.05<\mathrm{P} \leq 0.10 ; * \mathrm{P} \leq 0.05 ; * * \mathrm{P} \leq 0.01$.

\begin{tabular}{|c|c|c|c|c|c|c|}
\hline Community-type: & Aquatic pond & Grassy pond & Herbaceous meadow & Wet forest & $\begin{array}{c}\text { Carex walteriana } \\
\text { meadow }\end{array}$ & Mesic forest \\
\hline Number of bays in sample & 10 & 9 & 13 & 6 & 5 & 13 \\
\hline Diagnostic species & Nymphaea odorata & Panicum hemitomon & Leersia hexandra & $\begin{array}{l}\text { Nyssa sylvatica } \\
\text { var. biflora }\end{array}$ & Carex walteriana & Liquidambar styraciflua \\
\hline $\begin{array}{l}\text { Associated species } \\
\text { (constancy } \geq 70 \% \text { and/or } \\
\text { high relative abundance } \\
\text { in bays of the type) }\end{array}$ & $\begin{array}{c}\text { Panicum hemitomon } \\
\text { Brasenia schreberi } \\
\text { Eleocharis equisetoides } \\
\text { Leersia hexandra } \\
\text { Nyssa sylvatica } \\
\text { var. biflora }\end{array}$ & $\begin{array}{l}\text { Nyssa sylvatica } \\
\text { var. biflora } \\
\text { Cephalanthus } \\
\text { occidentalis } \\
\text { Rhexia spp. (excl. } \\
\text { R. aristosa) } \\
\text { Leersia hexandra }\end{array}$ & $\begin{array}{l}\text { Eleocharis melanocarpa } \\
\text { Ludwigia spp. } \\
\text { Proserpinaca spp. } \\
\text { Eleocharis robbinsii } \\
\text { Rhexia spp. (incl. } \\
\text { R. aristosa) } \\
\text { Bidens spp. } \\
\text { Diodia spp. }\end{array}$ & $\begin{array}{l}\text { Taxodium spp. } \\
\text { Cephalanthus } \\
\text { occidentalis }\end{array}$ & $\begin{array}{c}\text { Nyssa sylvatica } \\
\text { var. biflora } \\
\text { Cephalanthus } \\
\text { occidentalis } \\
\text { Panicum hemitomon } \\
\text { Taxodium spp. } \\
\text { Acer rubrum } \\
\text { Liquidambar styraciflua }\end{array}$ & $\begin{array}{c}\text { Acer rubrum } \\
\text { Smilax spp. } \\
\text { Campsis radicans } \\
\text { Cephalanthus } \\
\text { occidentalis } \\
\text { Nyssa sylvatica var. } \\
\text { sylvatica } \\
\text { Ulmus americana }\end{array}$ \\
\hline No. of species per bay & $22(2)$ & $21(3)$ & $20(3)$ & $18(3)$ & $26(5) \S$ & $22(2)$ \\
\hline Bay area $(\mathrm{ha})^{*}$ & $7.3(1.8)$ & $3.8(1.0)$ & $3.4(0.9)$ & $2.7(0.8)$ & $3.7(0.7)$ & $\underline{3.0}(0.6)$ \\
\hline $\begin{array}{l}\% \text { of sample units with } \\
\text { canopy/mid-story strata** }\end{array}$ & $\underline{18}(4)$ & $43(8)$ & $\underline{15}(4)$ & $79(10)$ & $43(12)$ & $87(5)$ \\
\hline 1996 hydroperiod index* & $1.3(0.1)$ & $1.9(0.4)$ & $2.5(0.3)$ & $1.8(0.5)$ & $2.1(0.6)$ & $2.8(0.2)$ \\
\hline Sand depth (in) + & $27(6)$ & $24(6)$ & $35(6)$ & $11(2)$ & $28(6)$ & $\underline{16}(3)$ \\
\hline Topsoil N (\%)** & $0.50(0.10)$ & $0.63(0.21)$ & $\underline{0.18}(0.03)$ & $0.53(0.18)$ & $0.29(0.12)$ & $0.21(0.06)$ \\
\hline 1951 disturbance index ${ }^{* *}$ & $1.3(0.4)$ & $2.2(0.4)$ & $2.5(0.4)$ & $\underline{0.5}(0.3)$ & $1.8(0.6)$ & $3.1(0.4)$ \\
\hline
\end{tabular}

§ Excluding bay from Middle Coastal Plain with $n=57$ species 
TABLE 4. Regional landscape distribution of Carolina bay community-types. Values are the number of bays (of $n=57$ ) found in each soil/landform area. Omitting the unclassified bay: $\chi^{2}=19.0, \mathrm{df}=10, P \leq 0.05$. Strong associations are noted in boldface.

\begin{tabular}{|c|c|c|c|c|}
\hline \multirow[b]{2}{*}{ Community-type: } & \multicolumn{3}{|c|}{ Soil/landform area } & \multirow[b]{2}{*}{$n$} \\
\hline & $\begin{array}{c}\text { Sandhills } \\
\text { uplands }\end{array}$ & $\begin{array}{c}\text { Coastal Plain } \\
\text { uplands }\end{array}$ & $\begin{array}{c}\text { Coastal Plain } \\
\text { terraces }\end{array}$ & \\
\hline Aquatic pond & 4 & 4 & 2 & 10 \\
\hline Grassy pond & 2 & 3 & 4 & 9 \\
\hline Herbaceous meadow & 7 & $3 \S$ & 3 & 13 \\
\hline Wet forest & 2 & 2 & 2 & 6 \\
\hline $\begin{array}{l}\text { Carex walteriana } \\
\text { meadow }\end{array}$ & 0 & $1 \S \S$ & 4 & 5 \\
\hline Mesic forest & 1 & 10 & 2 & 13 \\
\hline Ambiguous (unclassified) & 1 & - & - & 1 \\
\hline
\end{tabular}




\section{Landscape correlates of environmental drivers}

Not unexpectedly, the analyses clearly identified hydrology as a key environmental correlate ("driver") of vegetation pattern. Soil type and bay size also distinguish some vegetation types. Because soil features and size are readily identified at the individual bay level, they can serve as potential predictors of post-restoration vegetation, provided that expected hydrology can be estimated in some way. However, the results from our study suggest that hydrology is not readily predictable from the individual bay features we examined.

Irrespective of their landscape location or their soils, larger bays ( $>350 \mathrm{~m}$ length, or $\geq \mathrm{ca}$. 810 ha in area) are likely to have long hydroperiods and thus support aquatic pond vegetation (significant Pearson correlations of hydrologic measures with size). However, for bays smaller than this size threshold, size did not predict relative hydroperiod in any way (all correlations non-significant when large bays were omitted from analysis). This implies that other features (e.g. topographic position, watershed area, basin depth, soil water storage capacity) will play complex roles in determining the hydrologies of smaller bays. A bay's vegetation itself may affect hydrology if, for example, forested systems generate higher evapotranspiration losses than herb-dominated systems. Similarly, surrounding land cover (e.g. forested or non-forested buffer zones) could also influence bay hydrology, but these effects are largely unexplored (see App. B).

Bay hydroperiod was not directly predictable from bay soil type (whether analyzed as sand depth over clay or as 'clayey' vs. sandy' textural types; cf. App. C), nor was bay soil type related to bay size (all Pearson correlations and/or ANOVAs non-significant). Since multivariate analyses showed that vegetation pattern was significantly related to soil textural type, the influence of soils on vegetation composition may be through variations in fertility and/or moisture-holding capacity during and after water-drawdowns.

Whereas bay characteristics in isolation are not necessarily predictive of hydrology, the important drivers of vegetation pattern are somewhat predictable from knowledge of the landscape setting. On the SRS, where the landscape setting could be characterized with greater accuracy, bays showed trends or significant differences in hydrology, soils, and size with respect to soil/landform area (Table 5a):

- Bay soils reflected their upland soils matrix in that "Sandhills" area bays were more likely to have sandy soils, whereas soils in bays of the Coastal Plain uplands were predominantly clayey (cf. App. C).

- Bays on river terraces had lower values of the hydrologic measures (indicating more stable hydroperiods), which is consistent with a high probability of groundwater inputs (Chmielewski 1996). Bays in the Sandhills area (i.e. Lower Three Runs and Salkahatchie watersheds) had a variety of hydrologies, but at least some appear to receive periodic inputs from groundwater (Lide et al. 1995, Chmielewski 1996). 
- In contrast, bays of the Coastal Plain uplands may be largely precipitation-fed (Chmielewski 1996), thus their hydrologies will depend even more strongly upon factors specific to individual bays. When large bays with predictably long hydroperiods are omitted from analysis, bays with clayey soils had shorter hydroperiods (1996 C.V. index) than sandy-soil bays only in the Coastal Plain uplands and not in the other landform areas (ANOVA: $\mathrm{F}$-value for soil type $\mathrm{x}$ landform interaction $=5.1 ; \mathrm{df}=2,24 ; \mathrm{P}<0.05$ ) (cf. also App. C).

- Bays on river terraces tend to be smaller than bays in the other areas (see also Kirkman et al. 1996) and thus, perhaps, are more likely to support forested communities (cf. Table 3). Their shapes are often atypical, and their subsoils may have features (e.g. gravel) suggesting fluvial processes. Thus some may actually represent a different, "bay-like" geomorphic feature of the bottomland landscape.

Historically, there were also landscape-related differences in landuse impacts to the bays on the SRS (Table 5a) that would also have influenced present-day vegetation composition. In 1951, agricultural landuses were most extensive in the Coastal Plain uplands, and bays here showed the highest levels of disturbances including ditching, draining, pasturing, and cultivation. To the extent that the clayey-soil bays in this area were shallowly-flooded with short hydroperiods, they may have been more susceptible to agricultural conversions. Many ditches were dug through the bays' interiors, and we have speculated that this might have served to promote downward drainage through the clay lenses of the Rembert soils in these uplands (App. C). Sandhills-area bays had the least apparent levels of disturbance to their interiors, which may simply reflect less extensive agricultural use of these more infertile parts of the landscape and/or difficulties in creating effective drainage in the sandy soils. Terraces were likely to have more forested land than other landform areas (cf. also De Steven 1994), a probable consequence of a greater extent of poorly-drained soils on this lower-elevation landform. Bays here may have been less disturbed because they were generally too wet to drain effectively (Kirkman et al. 1996).

Regional landscape patterns. For the sample of 22 bays outside of the SRS boundaries, few environmental and landuse patterns differed significantly across landform areas (Table 5b). This result may be a consequence of the less precise data available for these sites. Detailed hydrologic data were lacking, soil/landform areas were generalized at a coarser scale, and discrepancies in available information for the "Sandhills" bays of NW Allendale County suggest that these bays might be alternatively characterized as Middle Coastal Plain sites. Further, unlike on the SRS, bays in the region have been generally less protected and thus have been subject to greater and more recent disturbances. 
TABLE 5. Characteristics of Carolina bays across different soil/landform areas on the SRS (a) and in the surrounding region (b). Values are means and s.e. (in parentheses), except where indicated otherwise. Differences among soil/landform areas are tested by non-parametric Kruskal-Wallis or $\chi^{2}$ statistics (except hydroperiod index, which was tested by ANOVA). $+0.05<\mathrm{P} \leq 0.10 ; * \mathrm{P} \leq 0.05 ; * * \mathrm{P} \leq 0.01$.

a. Savannah River Site

Number of bays in sample

Size: bay area (ha) ${ }^{+}$

Soils :

$\%$ of bays with clayey soils ${ }^{+}$

mean sand depth over clayey subsoil (in)*

Hydrology ${ }^{1}$ :

probable water source

C.V. of seasonal water depth, all bays ${ }^{+}$

C.V., omitting large bays*

hydroperiod index, all bays ${ }^{+}$

hydroperiod index, omitting large bays*

\begin{tabular}{c}
\hline Sandhills \\
uplands
\end{tabular}

12

$4.5(1.0)$

25

$38(5)$

Soil/landform areas

Coastal Plain
uplands

Coastal Plain terraces

12

11

$2.2(0.4)$

$4.3(1.0)$

$$
2.2(0.4)
$$

73

58

$20(5)$

$\mathrm{sw}(+\mathrm{gw} ?) \quad \mathrm{sw} \quad \mathrm{sw}+\mathrm{gw}$

$\begin{array}{lll}1.3(0.3) & 1.4(0.3) & 0.7(0.2) \\ 1.6(0.3) & 1.5(0.3) & 0.7(0.2) \\ & & \\ 2.4(0.3) & 2.3(0.3) & 1.5(0.2) \\ 2.6(0.4) & 2.4(0.3) & 1.5(0.2)\end{array}$

Landuse history (from 1951 aerial photography):

bay disturbance index $2 * *$

$3.3(0.3)$

$2.7(0.4)$

extent of bay perimeter with trees (\%)

$40(10)$

$38(9)$

land cover types within $100 \mathrm{~m}$ of bay perimeter:

$\%$ of land open (mostly agricultural) **

$\%$ of land sparsely-treed (oldfields?) **

$58(10)$

42 (10)

$\%$ of land forested

$95(3)$

3 (2)

$2(1)$
$81(7)$

$10(5)$

$9(3)$

${ }^{1}$ probable source based on Chmielewski 1996, where sw = surface water (precipitation and sub-surface flow) and $\mathrm{gw}$ = groundwater; $\mathrm{CV}$ of depth is an inverse measure of hydroperiod for 1996 (dry year), where lower values indicate longer hydroperiods and higher values indicate shorter hydroperiods (cf. App. B); hydroperiod index is a 4point scale of hydrologic pattern in 1996, where $1=$ longest flooding duration and $4=$ shortest duration (cf. App. B).

${ }^{2}$ Disturbance index is a 5-point scale based on 1951 aerial photography, ranging from $0=$ no apparent alteration of the bay interior to $4=$ substantial intrusion of surrounding land use into the bay (see Methods). 
TABLE 5. (continued)

\begin{tabular}{|c|c|c|c|}
\hline b. Region (off-SRS) & $\begin{array}{c}\text { Sandhills } \\
\text { uplands }\end{array}$ & $\begin{array}{c}\text { Coastal Plain } \\
\text { uplands } \S\end{array}$ & $\begin{array}{c}\text { Coastal Plain } \\
\text { terrace }\end{array}$ \\
\hline Number of bays in sample & 5 & 11 & 5 \\
\hline \multicolumn{4}{|l|}{ Size: } \\
\hline bay area (ha) & $3.3(0.7)$ & $5.8(1.7)$ & $2.8(0.7)$ \\
\hline \multicolumn{4}{|l|}{ Soils : } \\
\hline$\%$ of bays with clayey soils & 80 & 91 & 60 \\
\hline mean sand depth over clayey subsoil (in) ${ }^{+}$ & $16(5)$ & $15(5)$ & $27(6)$ \\
\hline \multicolumn{4}{|l|}{ Hydrology $1:$} \\
\hline hydroperiod index, all bays & $1.9(0.4)$ & $2.2(0.3)$ & $2.8(0.4)$ \\
\hline hydroperiod index, omitting large bays & $1.9(0.4)$ & $2.4(0.3)$ & $2.8(0.4)$ \\
\hline \multicolumn{4}{|l|}{ Landuse history (from aerial photography): } \\
\hline bay disturbance index ${ }^{2}$ & $0.8(0.6)$ & $1.7(0.6)$ & $1.6(0.7)$ \\
\hline extent of bay perimeter with trees (\%) & $60(20)$ & $18(6)$ & $43(14)$ \\
\hline \multicolumn{4}{|c|}{ land cover types within $100 \mathrm{~m}$ of bay perimeter: } \\
\hline$\%$ of land open (agricultural)* & $29(17)$ & $89(8)$ & $80(12)$ \\
\hline$\%$ of land sparsely-treed (oldfields?) ${ }^{*}$ & $64(17)$ & $9(7)$ & $13(8)$ \\
\hline$\%$ of land forested & $7(6)$ & $1(1)$ & $6(6)$ \\
\hline
\end{tabular}

$\S$ excluding one bay from Middle Coastal Plain below the Orangeburg scarp

' hydroperiod index is a 4-point scale of hydrologic pattern in 1996 (dry year), where 1 = longest flooding duration and $4=$ shortest flooding duration (cf. App. B).

${ }^{2}$ Disturbance index is a 5-point scale based on historical aerial photography, ranging from $0=$ no apparent alteration of the bay interior to $4=$ substantial intrusion of surrounding land use into the bay (see Methods). 


\section{Vegetation dynamics and succession}

Because most SRS bays have remained undisturbed and unmanaged for over 40 years, they represent a potential system for identifying vegetation dynamics associated with varying site conditions. Understanding of dynamic processes provides basis for identifying restoration goals and for hypotheses of restoration outcomes and management needs.

\section{Historical patterns of vegetation change}

On the SRS, changes in bay cover types from 1951 to 1992 suggested several coarse-scale patterns of post-disturbance arccession (Kirkman et al. 1996): 1) bays converted to agricultural uses (implying hydrologic modification) are now generally forested; 2) hardwoods-dominated bays, especially on the Terrace landform, have typically remained forested, perhaps because these sites were too wet to develop for agriculture; 3) "herb-dominated" bays (ranging from ponds to wet meadows) have remained open communities, a stability attributed to hydrologic regime because bays were not deliberately burned and spread of upland management fires into wetlands was usually prevented.

We corroborated these patterns at the regional scale, with finer resolution at the level of present-day vegetation-types (Table 6):

- In $1951,87 \%$ of the 57 survey bays were either open or only sparsely-treed, and today $85 \%$ of these bays still support open or sparsely-forested vegetation (aquatic or grassy ponds, meadows). Given widespread fire supression in this regional landscape, maintainence of open conditions is a result of permanent flooding (e.g. in large, undrained ponds) and/or a role of coarse-textured soils (deep sands) in retarding successful establishment of woody plants. All present-day herbaceous meadows were also open in 1951, but this apparent long-term persistence masks considerable dynamism. Many of these meadows have peripheral zones of pines that established and then died back during cycles of drought and re-flooding (cf. Kirkman 1992, De Steven 1994); this cyclic pattern is associated with typically sandy soils and specific landscape areas.

- Present-day mesic forests represent a directional succession on more fertile clayey soils where hydroperiods are typically very short (and perhaps altered by ditching and draining) (see also Bennett \& Nelson 1991). In 1951, nearly all these bays were open or only sparsely-treed (Table 6), 77\% were ditched (half through the interior), and they were associated with an upland landscape which was largely agricultural (cf. Tables 4 and 5).

- Forested bays are relatively stable (Table 6). Of 7 bays that were forested in 1951,5 have remained forested and typically support Nyssa-dominated "wet" forest. This suggests a persistent vegetation associated with less-disturbed bottomland areas, shallow flooding, clayey soils, and (probably) low fire frequency (see Kirkman et al. 1996). Two of the 7 bays lost forest cover following deep re-flooding and now support aquatic pond vegetation. One (\#40 on the SRS) represents a natural "restoration" by beaver activity, which blocked a large outflow ditch to create a deep pond that still contains remnant living Toxodium and Nyssa trees. 
TABLE 6. Transitions between 1951 bay cover types (open, sparsely-treed, or forested) and presentday (1993-96) vegetation types. Cell values are number of bays in each transition category. ${ }^{1}$

\begin{tabular}{|c|c|c|c|c|c|c|c|}
\hline \multirow[b]{2}{*}{1951 cover } & \multicolumn{6}{|c|}{ vegetation type (1993-96) } & \multirow[b]{2}{*}{$\begin{array}{c}\text { Row } \\
\text { totals }(\%)\end{array}$} \\
\hline & $\begin{array}{l}\text { Aquatic } \\
\text { pond }\end{array}$ & $\begin{array}{l}\text { Grassy } \\
\text { pond }\end{array}$ & $\begin{array}{c}\text { Herbaceous } \\
\text { meadow }\end{array}$ & $\begin{array}{c}\text { Wet } \\
\text { forest }\end{array}$ & $\begin{array}{l}\text { Carex } w . \\
\text { meadow }\end{array}$ & $\begin{array}{l}\text { Mesic } \\
\text { forest }\end{array}$ & \\
\hline open (non-forested) & 8 & 6 & 13 & 2 & 2 & 10 & $41(73)$ \\
\hline sparsely-treed & 0 & 3 & 0 & 0 & 3 & 2 & $8(14)$ \\
\hline forested & 2 & 0 & 0 & 4 & 0 & 1 & $7(12)$ \\
\hline Column totals $(\%)$ & $10(18)$ & $9(16)$ & $13(23)$ & $6(11)$ & $5(9)$ & $13(23)$ & 56 \\
\hline $\begin{array}{c}\text { mean \% } \\
\text { canopy/midstory }\end{array}$ & 18 & 43 & 15 & 79 & 43 & 87 & \\
\hline
\end{tabular}

${ }^{1}$ one unclassified bay (\#79) was open both in 1951 and in 1993 (20\% of sample units with midstory and/or canopy strata); during the interim, it had a sparse canopy of pines (possibly planted) that had died by 1993 
The few existing models have incorporated hydrology and fire as significant processes affecting bays within the Coastal Plain landscape. Bay vegetation is clearly most directly structured by hydrologic regime; several authors have proposed water depth and flooding duration (= hydroperiod) as two important aspects (e.g. Schalles 1979, Kirkman 1992; see also Richardson \& Gibbons 1993). Our analysis of hydrologic data for SRS bays suggests that these two aspects can be considered partially-independent parameters (App. B). Whereas deep-water bays generally have long hydroperiods, bays with shallower average seasonal depths can have differing hydroperiods depending upon factors such as ground-water inputs or other watershed features. To varying degrees, water levels fluctuate seasonally in all bays, particularly at the margins, and during prolonged droughts many bays may dry completely. Bay vegetation responds dynamically to this hydrologic variability. Water drawdowns promote recruitment of new species from dormant seed banks and permit less flood-tolerant species to colonize (e.g. Keough et al. 1989, Kirkman \& Sharitz 1994); droughts can favor the spread of upland fires into bays and thus further impact species composition. Re-flooding can reverse some changes, but others may persist for some time. In addition to the primary importance of hydrology, this study has shown that bay soil type and landform also influence vegetation composition and dynamics.

Building on Kirkman's conceptual model $(1992,1995)$, we suggest an expanded model based on the identified vegetation types and their associated dominant species (Fig. 6, p. 35). The intent is to indicate directions of vegetation change in response to changing hydrology and other processes at the whole-bay level, since a bay represents the "practical" management unit. The model suggests at least 2 successional pathways that differ with bay soil type (and, indirectly, with landscape). There are parallels in models of forest succession on mesic (fertile) and xeric (infertile) uplands (Jones et al. 1984).

The model in Figure 6 may be interpreted as follows:

- Irrespective of bay soil type, pond communities with aquatic macrophytes (e.g. Nymphaea odorata) will develop in large basins with deep and continuous flooding. Other plant species with varied flood tolerances will also be supported, since the bay margins can experience regular seasonal drawdowns even if central areas are flooded in most years. Bay margins with shallow slopes might be expected to support greater within-bay plant diversity than steeper perimeters.

- In smaller basins, or as hydrology changes, there are two divergent patterns of succession in bays with different soil types (next page). In general, progressive decreases in flooding depth and hydroperiod will favor succession towards forested wetlands. It is also expected that permanent drainage of bays would result in forests similar to those of the surrounding uplands. 
- On more fertile clayey soils, reduced flooding appears to favor vegetative expansion of robust, flood-tolerant graminoids such as Panicum hemitomon, along with colonization by bottomland hardwoods such as buttonbush (Cephalanthus occidentalis), swamp tupelo (Nyssa), and perhaps cypress (Taxodium). Given suitable conditions for tree recruitment, bays with shallow flooding of longer duration will support stable wet-forest communities. Short hydroperiods and/or artificial drainage favor succession to a more mesic forest with less flood-tolerant trees such as sweetgum (Liquidambar) and red maple (Acer rubrum). Deeper reflooding can be expected to reverse this pattern by causing mortality of floodingintolerant species. Fire could also reduce woody plant cover and maintain more open conditions; however, if not accompanied by hydrologic restoration, burning of mesic forest systems might favor increased pine colonization.

- In contrast, sandy bay soils appear to have favored the development of Leersiadominated herbaceous meadows, though $P$. hemitomon often co-occurs at least peripherally in some of these bays. Decreased hydroperiods and/or droughts promote colonization by pines (Pinus taeda, P. elliottii) that are intolerant of reflooding, thus resulting in a cyclic succession pattern that maintains open communities (Kirkman 1992, 1995). Permanent drainage would be expected to favor pine forest development, perhaps with xeric hardwoods. The cyclic pattern shows particular spatial association with the SRS "Sandhills" uplands of the Lower Three Runs and Salkahatchie River watersheds, but the underlying mechanisms are unclear. Variable hydrologies, perhaps from temporary ground-water inputs, are partially responsible. However, it is not certain whether the sandy substrates directly inhibit hardwood establishment during drawdowns, or whether the appropriate seed sources are generally absent in the surrounding xeric uplands.

From the available data, the successional roles of other significant species are less clear:

- Carex walteriana showed a clear spatial association with river terraces or lower topographic elevations. It forms nearly monodominant stands and is one of the few Carex that tolerates prolonged flooding (D. Reed, SEWRPC, pers. comm.). It occurred in bays with both clayey and sandy soils, but little is known of its site requirements apart from anecdotal evidence of association with burnouts of peat in some wetlands (D. Reed, pers. comm.). Like Panicumdominated grassy ponds, Carex meadows had peripheral zones of swamp tupelo that are likely to expand centrally unless prevented by prolonged flooding and/or periodic fires.

- Cypress (Taxodium ascendans and possibly $T$. distichum) is associated with swamp tupelo in wet-forest bays; it is also a sparser dominant in pond-cypress savannahs, which may have C. walteriana as an associate. Evidence suggests that fire suppression (and selective timbering) favor greater dominance by swamp tupelo, whereas moderate fire intensity may favor the more fire-resistant cypress. Pond-cypress savannahs are thought to be firemaintained as well (Ewel 1990; Bennett \& Nelson 1991). The influence of soil type on these communities is unclear, although cypress may be able to establish on sandy substrates with fluctuating hydroperiods. 


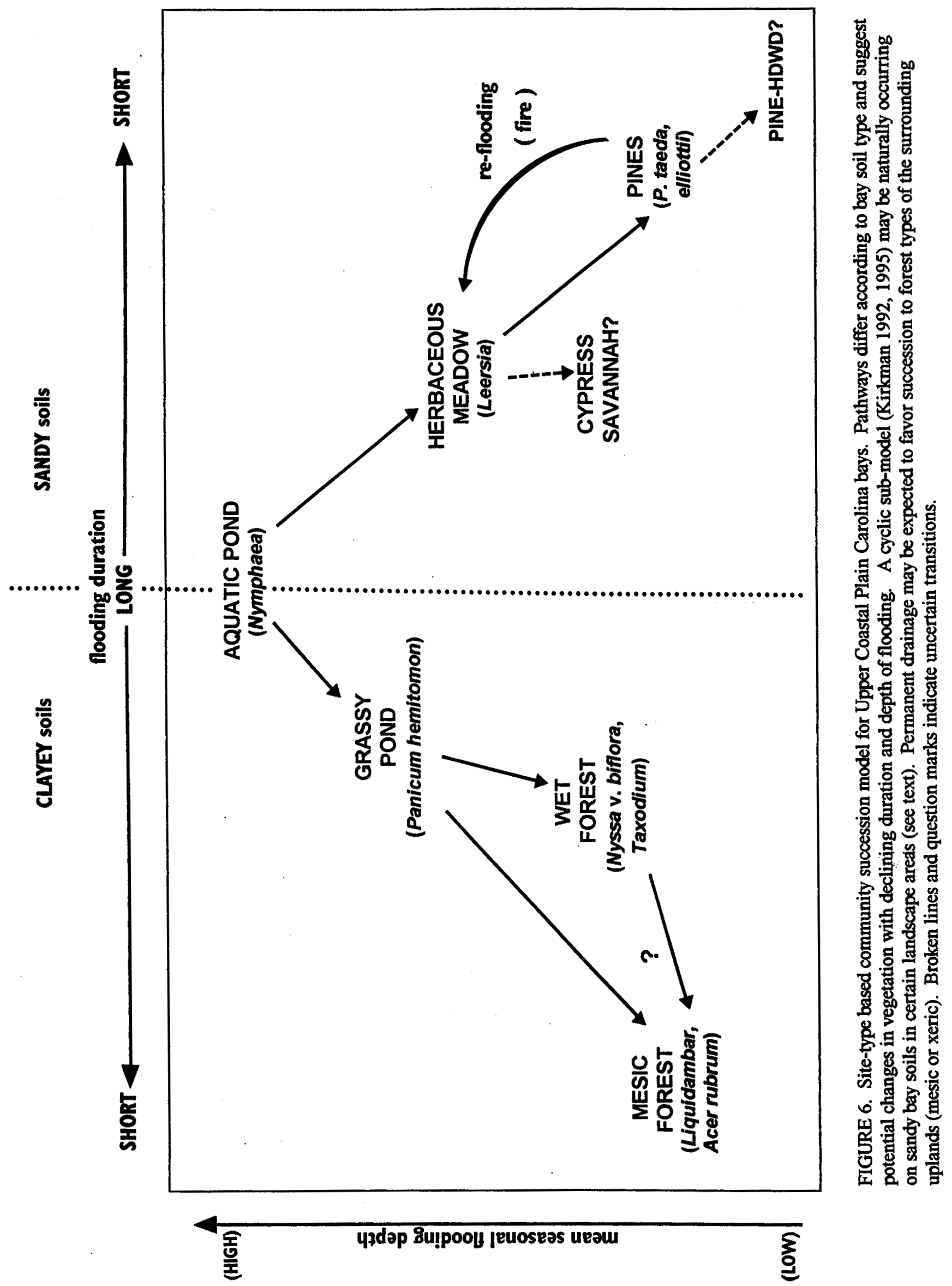


The model is only a generalization, but it is consistent with the available data and with the life history traits of the principal species (Table 7). Apart from the influence of basin size and soils, successional pathways could depend in part upon landscape position, since this may affect groundwater sources and chemistry.

Further, we cannot be sure of any persistent effects of historical and landscape factors. For example, patterns of forest development may have depended as much upon the proximity of differing seed sources as on hydrologic differences. Of the 6 wet-forest bays in the regional dataset, $5(83 \%)$ historically had adjacent bottomland or wetland forest within $100 \mathrm{~m}$ of their perimeters, whereas only 1 of $13(8 \%)$ mesic-forest bays had adjacent wetlands. Thus, the "regrowth" mesic-forest type may be associated with bays of Coastal Plains uplands because Liquidambar and other facultative species were prevalent in that landscape, although the type is also consistent with the short hydroperiods of these bays. Similarly, with the systems at hand we cannot know whether forested bays on clayey soils previously contained both Panicum and Leersia, which were then excluded through shading and drought stress as bays became colonized by hardwoods. Historical legacies may be long-lasting and complicate interpretations of succession. Changes in hydrologic regime may have promoted past colonization by woody plants; however, because many tree species are more flood-tolerant as adults than as seedlings, they can persist in bays for years after new hydrologic changes that might prevent any further tree recruitment. These are issues that can only be resolved through experimental study. 
TABLE 7. Life history traits and environmental tolerances of the significant species in Upper Coastal Plain Carolina bay communitytypes. Features in parentheses are inferred or assumed; $\mathbf{n} . \mathbf{d} .=$ features not described in the available literature.

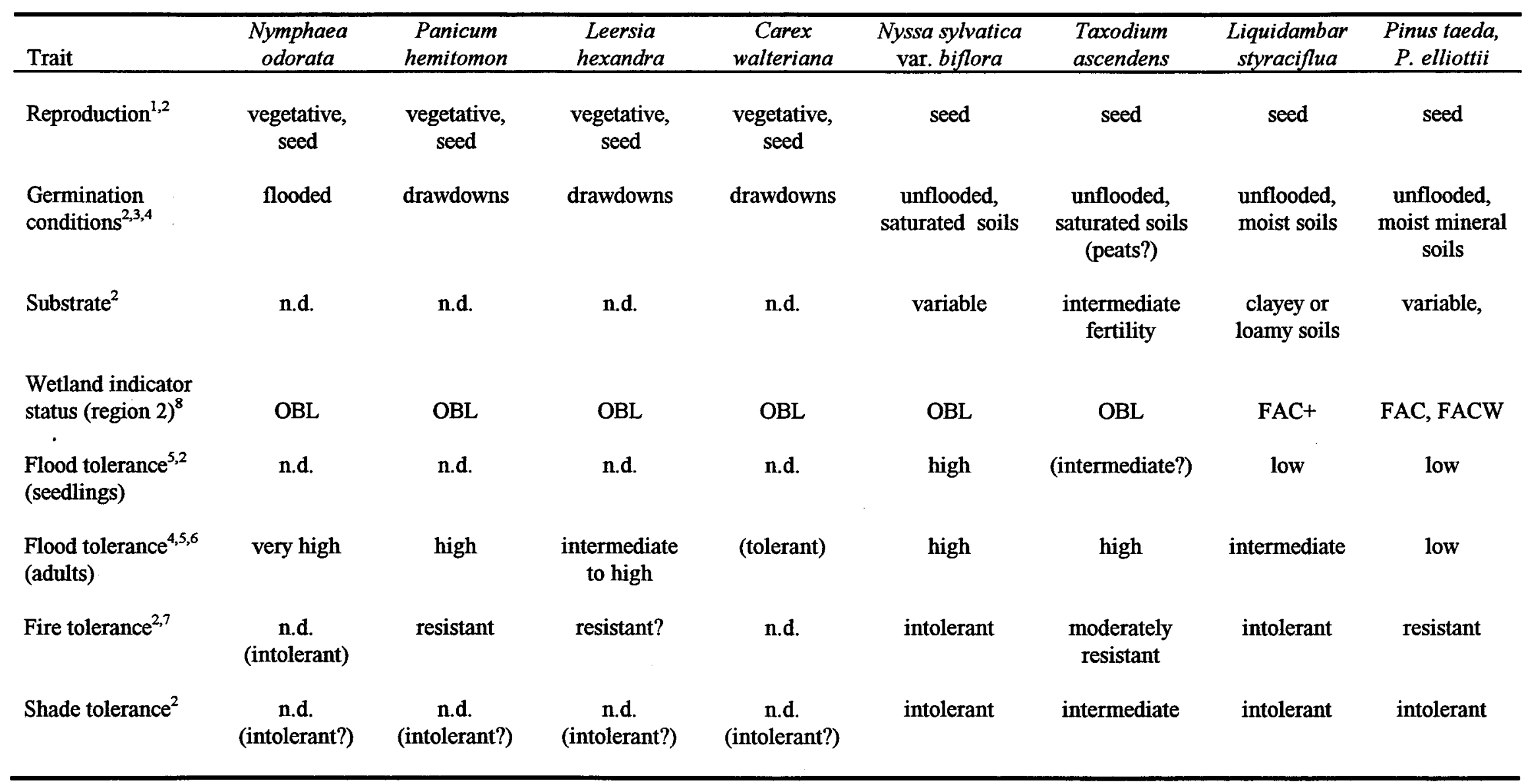

Note: flood tolerance is based on percent of growing season (very high $=>90 \%$, high $=60-90 \%$, intermediate $=30-60 \%$, and low $=<30 \%$ ).

Sources: ${ }^{1}$ Godfrey \& Wooten $(1979,1981) ;{ }^{2}$ Burns \& Honkala (1990 a,b); ${ }^{3}$ Conti \& Gunther (1984); ${ }^{4}$ Kushlan (1990); ${ }^{5}$ Teskey \& Hinckley (1977); ${ }^{6}$ Kirkman \& Sharitz (1993); ${ }^{7}$ Kirkman \& Sharitz (1994); ${ }^{8}$ Reed 1988 


\section{Conservation strategies and implications for bay vegetation restoration}

This study has indicated that diverse vegetation types can be characterized at the level of individual bays and that a significant degree of plant diversity is expressed in the floristic variety among bays. The gradient and classification analyses suggested a series of environmental "templates" for these plant communities (Table 8), and an implication is that conservation of regional diversity would be promoted by protecting bays with a variety of hydrologies and soils across different landscape areas. Landscape-specific protection and management strategies may be desireable because: 1) the distribution of community-types varies to some degree with landscape area, and 2) important ecological processes such as fire and hydrologic regime have general tendencies to vary across the landscape.

TABLE 8. Environmental templates for vegetation in bays of South Carolina's Upper Coastal Plain.

\begin{tabular}{|c|c|c|c|c|c|c|}
\hline $\begin{array}{l}\text { Environmental } \\
\text { variable }\end{array}$ & $\begin{array}{l}\text { Aquatic } \\
\text { pond }\end{array}$ & $\begin{array}{l}\text { Grassy } \\
\text { pond }\end{array}$ & $\begin{array}{c}\text { Herbaceous } \\
\text { meadow }\end{array}$ & Wet forest & $\begin{array}{c}\text { Carex } \\
\text { walteriana } \\
\text { meadow }\end{array}$ & Mesic forest \\
\hline Bay size & large & - & - & smaller? & - & smaller? \\
\hline $\begin{array}{l}\text { Flooding depth } \\
\text { and duration }\end{array}$ & $\begin{array}{l}\text { deep, } \\
\text { long }\end{array}$ & $\begin{array}{c}\text { shallow, } \\
\text { long }\end{array}$ & $\begin{array}{c}\text { shallow, } \\
\text { variable } \\
\text { (short during } \\
\text { dry years) }\end{array}$ & $\begin{array}{c}\text { shallow, } \\
\text { long }\end{array}$ & $\begin{array}{l}\text { shallow, } \\
\text { variable? }\end{array}$ & $\begin{array}{l}\text { very shallow, } \\
\text { short (spring } \\
\text { flooding only) }\end{array}$ \\
\hline Landform area & - & - & $\begin{array}{l}\text { "Sandhills" } \\
\text { uplands? }\end{array}$ & - & river terraces & $\begin{array}{c}\text { Coastal Plain } \\
\text { uplands }\end{array}$ \\
\hline $\begin{array}{l}\text { Topographic } \\
\text { position }\end{array}$ & - & - & - & lower & lower & higher? \\
\hline Soil type & $\begin{array}{c}\text { variable } \\
\text { (clayey?) }\end{array}$ & $\begin{array}{l}\text { variable } \\
\text { (clayey?) }\end{array}$ & sandy & clayey & $\begin{array}{l}\text { variable } \\
\text { (sandy?) }\end{array}$ & clayey \\
\hline Soil O.M. & higher & higher & lower & higher & - & - \\
\hline Past disturbance & - & - & - & lower & - & higher \\
\hline
\end{tabular}

Some community-types may be of special priority for conservation. Many rare plant species are associated with non-forested communities such as ponds and meadows, which may be relatively rare in the present-day landscape. Wet-forest bays have similar composition to other bottomland forests; however, particuarly on the terrace these bays also support evergreen trees (Magnolia virginiana, Persea borbonia) and shrubs (e.g. Lyonia, Leucothoe) that are more typical of pocosins and Outer Coastal Plain bays. 
The community-types can serve as potential goals for restoration of individual bays. Some environmental drivers (e.g. soil type) can be readily identified in a candidate site, whereas others (e.g. post-restoration hydrology) are less predictable. Along with this framework for "potential" vegetation, models of vegetation dynamics indicate possible site selection strategies and management options. The patterns are complex and may only be confirmed through experimental study. Given the uncertainties in our knowledge, the models represent hypotheses of vegetation response to restoration actions. We suggest some possible scenarios, assuming that restoration of candidate sites will involve attempts to increase hydroperiods to the extent supportable in each site:

- Restoration of large, deep basins should favor aquatic pond communities. Along with basin size, the site potential for this community might be inferred from the size of existing drainage ditches, with very large ditches presumably indicating a former deep-water system (e.g. SRS bay \#40). Timbering of appropriate forested bays could accelerate restoration, but leaving some trees to die slowly and create snags may enhance wildlife value.

- If herbaceous meadows are a restoration goal, then bays with deep, sandy soils should be preferentially selected, particularly in the "Sandhills" landform area. Timbering and perhaps burning of potentially-suitable forested sites could enhance restoration success. With restoration of appropriate hydrology, fire management may not be needed to prevent longterm tree encroachment, provided that the only woody colonists are flood-intolerant pines.

- The typical dominants of meadow communities (Leersia, Panicum, Carex) may tolerate fire and thus fire spread into such bays may be a permissible management action. However, Leersia-dominated bays may support more rare and threatened plant species than Panicumdominated bays, the latter often being denser and more marsh-like than meadow-like. Management research may be needed to ensure that burning does not encourage greater dominance by Panicum, since it co-occurs with Leersia in some herbaceous meadows.

- If hardwood-dominated communities are a restoration goal, then shallow bays with clayey soils should be preferentially selected. In the Coastal Plain uplands, soils with shallow clay lenses may promote the shorter hydroperiods that support forest development. Research on fire management may indicate the degree to which either swamp tupelo or cypress are differently favored. Research is also needed to determine if cypress establishment (e.g. as for pond-cypress savannah) is supportable on sandy bay soils (given suitable hydrology).

- Mesic forest bays appear be associated with considerable past disturbance and have species that commonly occur in upland habitats. Thus they could be candidates for restoration to more desireable community-types. Reversion to open systems might be achieved by increasing flooding depth and duration (where possible), but response in the form of tree death may be slow. However, the potential for such sites to support open communities is uncertain. Most are on clayey soils that generally favor succession to forest. It is not clear if mesic forest developed solely as a result of disturbance, or if such bays were historically mesic systems that were logged, ditched, and farmed because their short hydroperiods made drainage easier. Maintainence or restoration to wet forest may be a more efficient option if conversion to open systems would require intensive management in the form of repeated timbering and/or burning. 
- In all cases of reversion from forested to open communities, success will depend upon the presence of the desired species in the seedbank or on the proximity of seed sources, because long-distance colonization may be slow or unpredictable. If the desired species of open communities are absent, artificial seeding or planting may be necessary.

- Depending upon the post-restoration hydrology, the composition of vegetation buffer zones may have a substantial impact on bay vegetation, either as a potential seed source, as a "filter" of plant colonists from beyond the buffer zone (e.g. Poiani \& Dixon 1995), or as a modifier of hydrologic regime (see App. B). In effect, the successional model postulates interactions between landscape, bay soils, and type of woody plant encroachment (hardwoods or pines).

Despite the uncertainties, this study has shown that study at the whole-bay level can provide reasonable set of community-types and environmental templates for Carolina bay vegetation. The proposed SRFS Carolina bay restoration study has strong potential as a research system for testing hypotheses and for assessing methodologies for restoration and management, both of the bays themselves and for their adjacent buffer zones. 


\section{LITERATURE CITED}

Beals, E.W. 1984. Bray-Curtis ordination: an effective strategy for analysis of multivariate ecological data. Advances in Ecological Research 14:1-55.

Bennett, S.H. \& J.B. Nelson 1991. Distribution and status of Carolina bays in South Carolina. Nongame and Heritage Trust Publications No. 1. South Carolina Wildlife \& Marine Resources Dept., Columbia, SC.

Burns, R.M. \& B.H. Honkala, tech. coords. 1990a. Silvics of North America. Vol. 1: Conifers. Agriculture Handbook 654. USDA Forest Service, Washington, D.C. 675 p.

1990b. Silvics of North America. Vol. 2: Hardwoods. Agriculture Handbook 654. USDA Forest Service, Washington, D.C. 877 p.

Chmielewski, R.M. 1996. Hydrologic analysis of Carolina bay wetlands at the Savannah River Site, South Carolina. M.S. thesis, University of Wisconsin-Milwaukee, Milwaukee WI. 63 pp.

Conti, R.S. \& P.P. Gunther. 1984. Relations of phenology and seed germination to the distribution of dominant plants in Okefenokee Swamp. Pages 144 - 167 in A.D. Cohen, D.J. Casagrande, M.J. Andrejko and G.R. Best, eds. The Okefenokee Swamp: its natural history, geology and geochemistry. Wetland Surveys. Los Alamos, N.M.

De Steven, D. 1994. Patterns of vegetation diversity among Carolina bays and depression wetlands on the Savannah River Site, South Carolina. Unpub. report. 35 pp.

Ewel, K.C. 1990. Swamps. Pp. 321-317 in R.L. Myers \& J.J. Ewel (eds.), Ecosystems of Florida. Univ. of Central Florida Press, Orlando, FL.

Godfrey, R.K. \& J.W. Wooten 1979. Aquatic and wetland plants of Southeastern United States. Monocotyledons. University of GA Press, Athens, GA. $712 \mathrm{pp}$.

1981. Aquatic and wetland plants of Southeastern United States. Dicotyledons. University of GA Press, Athens, GA. $933 \mathrm{pp}$.

Jones, S.M., D.H. Van Lear, \& S.K. Cox 1984. A vegetation-landform classification of forest sites within the Upper Coastal Plain of South Carolina. Bull. Torr. Botan. Club 111:349-60.

Keough, J., G.R. Guntenspergen, \& J. Grace 1989. Vegetation and hydrologic characteristics of Carolina bays. Unpub. report. for the Savannah River Ecology Laboratory, SRS.

Kirkman, L.K. 1992. Cyclical vegetation dynamics in Carolina bay wetlands. Ph.D. dissertation, Unviersity of Georgia, Athens, GA.

1995. Impacts of fire and hydrological regimes on vegetation in depression wetlands of Southeastern USA. Pp. 10-20 in S.I. Cerulean \& R.T. Engstrom (eds.), Fire in Wetlands: a Management Perspective. Proceedings 19th Tall Timbers Fire Ecology Conf., Tall Timbers Research Inc., Tallahassee, FL.

Kirkman, L.K., R.F. Lide, G.Wein \& R.R. Sharitz 1996. Vegetation changes and land-use legacies of depression wetlands of the western Coastal plain of South Carolina: 1951-1992. Wetlands 16: 564-76.

Kirkman, L.K. \& R.R. Sharitz. 1993. Growth in controlled water regimes of three grasses common in freshwater wetlands of the southeastern USA. Aquatic Botany 44: 345-359.

1994. Vegetation disturbance and maintenance of diversity in intermittently flooded Carolina bays in South Carolina. Ecological Applications 4:177-188.

Knox, J.N. \& R.R. Sharitz 1990. Endangered, threatened, and rare vascular flora of the Savannah River Site. SRO-NERP-20.

Kushlan, J.A. 1990. Freshwater marshes. Pages 324 -364 in R.L. Myers and J.J. Ewel, eds. Ecosystems of Florida. University of Central Florida Press, Orlando, FL.

Lide, R.F. 1994. Carolina bays and similar natural depression wetlands of theSRS. GIS coverage in ARC/INFO. Savannah River Ecology Lab, Savannah River Site. 
Lide, R.F., V.G. Meentemeyer, J.E. Pinder III, \& L.M. Beatty 1995. Hydrology of a Carolina bay located on the Upper Coastal Plain of western South Carolina. Wetlands 15:47-57.

Maybin, A.H. \& P.G. Nystrom, Jr. 1995. Geologic map of South Carolina. SC Geological Survey, Columbia, SC.

McCune, B. \& M.J. Mefford 1995. PC-ORD. Multivariate Analysis of Ecological Data, Version 2.0. MjM Software Design, Gleneden Beach, OR.

Natural Resources Conservation Service 1994. State Soil Geographic (STATSGO) Data Base. USDA Soil Conservation Service Miscell. Publ. 1492.

Nystrom, P.G. Jr., R.H. Wiloughby, \& L.E. Kite 1986. Cretaceous-Tertiary stratigraphy of the upper edge of the Coastal Plain between North Augusta and Lexington, South Carolina. Carolina Geological Society Field Trip Guidebook, SC Geological Survey, Columbia, SC. 82 pp.

Peet, R.K. \& N.L. Christensen 1980. Hardwood forest vegetation of the North Carolina piedmont. Veröff. Geobot. Inst. ETH, Stiftung Rübel, Zürich 69. Heft. pp. 14-39.

Poiani, K.A. \& P.M. Dixon 1995. Seed banks of Carolina bays: potential contributions from surrounding landscape vegetation. Am. Midl. Nat. 134:140-54.

Porcher, R.D. Jr. 1966. A floristic study of the vascular plants in nine selected bays in Berkeley County, South Carolina. M.S. thesis, University of South Carolina, Columbia, SC.

Prowell, D.C. 1994. Preliminary geologic map of the Barnwell 30' x 60' quadrangle, South Carolina and Georgia. Open-File Report 94-673, U.S. Geological Survey, Atlanta, GA.

Reed, P. B. Jr. 1988. National list of plant species that occur in wetlands: national summary. U.S. Fish \& Wildlife Service Biological Report 88 (24). 244 pp.

Richardson, C.J. \& J.Whitfield Gibbons 1993. Pocosins, Carolina bays, and mountain bogs. Pp. 257310 in W.H. Martin, S.G. Boyce, \& A.C. Echternacht (eds.), Biodiversity of the Southeastern United States/Lowland Terrestrial Communities. John Wiley\&Sons, Inc.

Rogers, V.A. 1990. Soil survey of Savannah River Plant area, parts of Aiken, Barnwell, and Allendale Counties, South Carolina. USDA Soil Conservation Service.

Schalles, J.F. 1979. Comparative limnology and ecosystem analysis of Carolina bay ponds on the upper Coastal Plain of South Carolina. PhD dissertation, Emory University, Atlanta, GA.

Schalles, J.F., R.R. Sharitz, J.W. Gibbons, G.J. Leversee \& J.N. Knox 1989. Carolina bays of the Savannah River Plant. SRO-NERP-18.

Tausch, R.J., D.A. Charlet, D.A. Weixelman \& D.C. Zamudio 1995. Patterns of ordination and classification instability resulting from changes in input data order. J. Veg. Science 6:897902.

Ter Braak, C.J.F. 1988. CANOCO- a FORTRAN program for Canonical Community Ordination. Microcomputer Power, Ithaca, NY.

1990. CANOCO- a FORTRAN program for Canonical Community Ordination. Update Notes, Version 3.10. 35 pp.

Teskey, R.O. \& T.M. Hinckley. 1977. Impact of water level changes on woody riparian and wetland communities. Vol.2. Southern Forest Region. US Fish and Wildlife Service OBS- 77/59.

Tyndall, W. K.A. McCarthy, J.C. Ludwig \& A. Rome 1990. Vegetation of six Carolina bays in Maryland. Castanea 55:1-21.

U.S. Department of Energy, SRO 1993. Information for mitigation of wetlands impacts at the Savannah River Site. Report, Environmental and Laboratory Programs Division. 40 pp.

U.S. Department of Energy, SRS 1993. An integrated biological diversity research program at the Savannah River Site. Draft report. $10 \mathrm{pp}$.

Workman, S.W. \& K.W. McLeod 1990. Vegetation of the Savannah River Site: Major Community Types. SRO-NERP-19. 
APPENDIX A. Summary features of Carolina bays used in the survey.

\begin{tabular}{|c|c|c|c|c|c|c|c|c|c|}
\hline $\begin{array}{l}\text { I.D. } \\
\text { No. }\end{array}$ & $\begin{array}{l}\text { Site or } \\
\text { County }\end{array}$ & $\begin{array}{c}\text { Map } \\
\text { elev (ft) }\end{array}$ & $\begin{array}{c}\text { Bay } \\
\text { length (m) }\end{array}$ & $\begin{array}{c}\text { Bay } \\
\text { area (ha) }\end{array}$ & $\begin{array}{c}\text { Soil//andform } \\
\text { area }\end{array}$ & $\begin{array}{c}\text { Surficial } \\
\text { geologic unit }\end{array}$ & $\begin{array}{l}\text { Bay soil } \\
\text { series }\end{array}$ & $\begin{array}{l}\text { Adjacent upland } \\
\text { soil series }\end{array}$ & $\begin{array}{l}\text { Bay community-type } \\
\text { (see bay classification section) }\end{array}$ \\
\hline 3 & SRS & 310 & 480 & 11.2 & coastal plain (sand) & Tu & Rembert & Dothan/Ocilla & grassy pond \\
\hline 7 & SRS & 150 & 120 & 0.9 & terrace & Qa12 & Rembert & Ailey & grassy pond \\
\hline 9 & SRS & 170 & 290 & 3.9 & terrace & Qa12 & Rembert & Dothan & grassy pond \\
\hline 11 & SRS & 170 & 120 & 1.3 & terrace & Qal2/Tm & Rembert & Dothan & grassy pond \\
\hline 26 & SRS & 140 & 156 & 1.2 & terrace & Qa12 & Ogeechee & Dothan & herbaceous meadow \\
\hline 27 & SRS & 140 & 200 & 2.3 & terrace & Qal2 & Ogeechee & Dothan & herbaceous meadow \\
\hline 40 & SRS & 320 & 300 & 7.5 & coastal plain (sand) & Tu & Pelham * & Dothan & aquatic pond \\
\hline 44 & SRS & 340 & 330 & 8.1 & coastal plain (sand) & $\mathrm{Tu}$ & Rembert & Blanton & mesic forest \\
\hline 64 & SRS & 250 & 155 & 4.4 & sandhills & $\mathrm{Td}$ & Ogeechee & Blanton & grassy pond \\
\hline 66 & SRS & 280 & 480 & 11.7 & sandhills & Td & Ogeechee & Ailey & herbaceous meadow \\
\hline 67 & SRS & 280 & 220 & 9.5 & sandhills & $\mathrm{Td}$ & Ogeechee & Ailey & herbaceous meadow \\
\hline 78 & SRS & 260 & 180 & 4.5 & sandhills & Td & Ogeechee & Albany & aquatic pond \\
\hline 79 & SRS & 260 & 130 & 2.8 & sandhills & $\mathbf{T d}$ & Ogeechee & Blanton & ambiguous (unclassified) \\
\hline 80 & SRS & 260 & 240 & 2.2 & sandhills & Td & Rembert & Blanton & wet forest \\
\hline 82 & SRS & 240 & 260 & 2.9 & sandhills & $\mathrm{Ttr} / \mathrm{Tu} / \mathrm{Td}$ & Rembert & Ailey & grassy pond \\
\hline 83 & SRS & 200 & 380 & 8.6 & sandhills & Ttr & Ogeechee * & Wagram/Ailey & aquatic pond \\
\hline 87 & SRS & 160 & 250 & 1.8 & sandhills & $\mathrm{Tdb}$ & Ogeechee & Albany & herbaceous meadow \\
\hline 88 & SRS & 190 & 110 & 0.4 & sandhills & Ttr & Williman & Lakeland & herbaceous meadow \\
\hline 92 & SRS & 270 & 190 & 5.5 & coastal plain (sand) & $\mathrm{Tu}$ & Rembert & Dothan & mesic forest \\
\hline 106 & SRS & 260 & 220 & 2.5 & sandhills? & $\mathrm{Tu} / \mathrm{Td}$ & Williman & Ailey & herbaceous meadow \\
\hline 107 & SRS & 280 & 220 & 3.1 & sandhills? & $\mathrm{Tu} / \mathrm{Td}$ & Rembert & Dothan & mesic forest \\
\hline 118 & SRS & 300 & 150 & 1.5 & coastal plain (sand) & $\mathrm{Tu}$ & Rembert-Ogeechee & Norfolk & mesic forest \\
\hline 123 & SRS & 290 & 129 & 1.4 & coastal plain (sand) & $\mathrm{Tu}$ & Rembert * & Dothan & grassy pond \\
\hline 127 & SRS & 260 & 290 & 5.1 & coastal plain (sand) & $\mathrm{Tu}$ & Williman & Wagram & grassy pond \\
\hline 132 & SRS & 260 & 250 & 2.6 & coastal plain (sand) & $\mathrm{Ttr} / \mathrm{Tu}$ & Rembert & Dothan & mesic forest \\
\hline 136 & SRS & 130 & 190 & 1.2 & terrace & Qa12 & Coxville & Norfolk & Carex walteriana meadow \\
\hline 138 & SRS & 130 & 150 & 1.4 & terrace & Qa12 & Rembert & Dothan & wet forest \\
\hline 139 & SRS & 130 & 260 & 1.4 & terrace & Qal2 & Rembert & Lucy & wet forest \\
\hline 142 & SRS & 130 & 430 & 5.3 & terrace & Qal2/Tdb & Williman * & Blanton & aquatic pond \\
\hline 154 & SRS & 120 & 110 & 0.5 & terrace & Qa12 & Rembert & Wagram & mesic forest \\
\hline 165 & SRS & 140 & 288 & 3.8 & terrace & Qal2 & Williman & Norfolk & Carex walteriana meadow \\
\hline 170 & SRS & 150 & 310 & 2.7 & terrace & Qal2 & Ogeechee & Ocilla & grassy pond \\
\hline 171 & SRS & 270 & 160 & 1.8 & coastal plain (sand) & $\mathrm{Tu}$ & Rembert & Orangeburg & mesic forest \\
\hline 189 & SRS & 300 & 170 & 1.2 & coastal plain (sand) & $\mathrm{Tu}$ & Rembert & Dothan/Fuquay & mesic forest \\
\hline 5084 & SRS & 320 & 130 & 1.7 & coastal plain (sand) & $\mathrm{Tu}$ & Ogeechee-Rembert & Dothan & mesic forest \\
\hline
\end{tabular}


APPENDIX A. (continued)

\begin{tabular}{|c|c|c|c|c|c|c|c|c|c|}
\hline $\begin{array}{l}\text { I.D. } \\
\text { No. }\end{array}$ & $\begin{array}{l}\text { Site or } \\
\text { County }\end{array}$ & $\begin{array}{l}\text { Map } \\
\text { elev (ft) }\end{array}$ & $\begin{array}{c}\text { Bay } \\
\text { length }(m)\end{array}$ & $\begin{array}{c}\text { Bay } \\
\text { area (ha) }\end{array}$ & $\begin{array}{c}\text { Soil/landform } \\
\text { area }\end{array}$ & $\begin{array}{l}\text { Surficial } \\
\text { geologic unit }\end{array}$ & $\begin{array}{l}\text { Bay soil } \\
\text { series }\end{array}$ & $\begin{array}{l}\text { Adjacent upland } \\
\text { soil series }\end{array}$ & $\begin{array}{l}\text { Bay community-type } \\
\text { (see bay classification section) }\end{array}$ \\
\hline 603 & Aiken & 620 & 200 & 2.9 & coastal plain (sand) & $\mathrm{Tu}$ & Rembert & Bonneau & herbaceous meadow \\
\hline 604 & Aiken & 620 & 200 & 1.6 & coastal plain (sand) & Tu & Rembert & Ocilla & herbaceous meadow \\
\hline 605 & Saluda & 640 & 290 & 6.4 & coastal plain (sand) & $\mathrm{Tu}$ & Rembert & Bonneau & aquatic pond \\
\hline 608 & Allendale & 220 & 290 & 5.4 & sandhills? & $\mathrm{Tu}$ & Rembert & Ocilla & aquatic pond \\
\hline 612 & Allendale & 200 & 180 & 2.0 & sandhills? & $\mathrm{Tu}$ & Rembert * & Troup & wet forest (pond cypress pond?) \\
\hline 615 & Allendale & 180 & 190 & 1.3 & sandhills? & $\mathrm{Tu}$ & Rembert & Lynchburg & aquatic pond \\
\hline 625 & Bamberg & 170 & 290 & 6.6 & coastal plain (clay) & $\operatorname{Ttr} / \mathrm{Tu}$ & Rembert & Neeses & wet forest \\
\hline 636 & Richland & 160 & 270 & 4.7 & terrace & Qal2? Tp? & Ogeechee-Rembert & Noboco & C. walteriana meadow \\
\hline 638 & Barnwell & 320 & 210 & 2.6 & coastal plain (clay) & Tu & Rembert & Lynchburg & wet forest \\
\hline 639 & Barnwell & 260 & 450 & 12.5 & coastal plain (sand) & $\mathrm{Tu}$ & Rembert & Gilead & aquatic pond \\
\hline 643 & Aiken & 170 & 215 & 3.3 & terrace & Qa12 & Ogëechee & Lynchburg & C. walteriana meadow \\
\hline 644 & Aiken & 125 & 105 & 1.2 & terrace & Qa12 & Rembert & Ocilla & herbaceous meadow \\
\hline 645 & Aiken & 180 & 190 & 3.3 & terrace & Qal2/Thc & Rembert-Plummer & Blanton & mesic forest \\
\hline 652 & Saluda & 630 & 140 & 1.6 & coastal plain (sand) & $\mathbf{T u}$ & Plummer-Pelham & Albany & herbaceous meadow \\
\hline 670 & Edgefield & 600 & 500 & 20.3 & coastal plain (clay) & Tu & Rembert & Albany & aquatic pond \\
\hline 680 & Chem Nuclea: & 260 & 190 & 4.0 & sandhills & $\mathrm{Td}$ & Ogeechee-McColl & Blanton & herbaceous meadow \\
\hline 682 & Chem Nuclea: & 250 & 210 & 4.0 & sandhills & $\mathrm{Td}$ & Rembert & Ailey & herbaceous meadow \\
\hline 691 & Bamberg & 200 & 150 & 1.2 & coastal plain (clay) & $\mathrm{Ttr} / \mathrm{Tu}$ & Rembert & Lynchburg & mesic forest \\
\hline 692 & Bamberg & 220 & 270 & 5.3 & coastal plain (clay) & Tu & Rembert & Bonneau & mesic forest \\
\hline 693 & Bamberg & 230 & 220 & 3.3 & coastal plain (clay) & Tu & Rembert & Barnwell (Dothan) & mesic forest \\
\hline 696 & Allendale & 120 & 160 & 1.3 & terrace (mcp?) & Ttr? & Rembert & Lynchburg & aquatic pond \\
\hline 699 & Orangeburg & 140 & 300 & 5.6 & mcp & Tp? & Ogeechee & Ocilla & C. walteriana meadow (cyp. savannah?) \\
\hline
\end{tabular}

elevation: from USGS 7.5' quadrangle maps $(1: 24,000)$

bay length: long-axis field transect

soil/landform area:-from interpretation of generalized soil map; '?' indicates uncertainty of generalization for Allendale County sites (see text)

geologic units: $\mathrm{Td}=$ Dune Sand; $\mathrm{Tu}=$ Upland (Citronelle); $\mathrm{Ttr}=$ Tobacco Road Sand; $\mathrm{Tdb}=$ Dry Branch Formation; Thc $=$ Huber Formation; $\mathrm{Qa12}=\mathrm{Quaternary}$ alluvium ( $?$ = estimate or possible alternative, map not available; $' /$ ' indicates scarp adjacent to bay location)

bay soil series: uniform or 'typical' series for $n=1-4$ field profiles in each bay; where $n=2$ and profiles differed, both series are given

( ${ }^{*}$ ' indicates that bay center could not be sampled because of high water depth, thus soil series may not be fully representative ) 
APPENDIX B. Characterization of Carolina bay hydrology.

\section{Hydrology measures for SRS bays}

Hydrology of SRS bays was characterized from weekly measurements of water depth at the center of each bay (provided by R. Lide, SREL). Staff gages were first installed in 1995, so data were available for 1995-1996. Fortuitously, 1995 was a wet year (annual ppt $=68.1$ " for the water year Oct 1994-Sep 1995 at Blackville 3W station) and 1996 was a dry year (annual ppt $=37.9^{\prime \prime}$ ). Bays filled to their maximum depths by late March or April and drew down to their lowest levels by late November or early December. Therefore we defined a water 'season' of April-November $(n=8 \mathrm{mo})$ to develop several simple measures of hydrology. To smooth out the effects of transient weekly changes in water level and to compensate for gage placement in ditches and atypical depressions, we used the monthly averages of the weekly gage readings (i.e. mean weekly depth per month) to calculate 3 measures for each bay in each year:

1) mean seasonal depth $=$ the average monthly water depth from April-November

2) coefficient of variation (C.V.) of average monthly water depth from April-November $(\mathrm{C} . \mathrm{V} .=$ s.d./mean, expressed as a fraction)

3) number of months flooded = sum of months from April-November that the bay was 'flooded' (defined as a mean weekly depth $\geq 10 \mathrm{~cm}$ per month, based on the finding that any month with a lesser mean depth was dry for the majority of its weeks)

All measures are highly correlated (Table B1) but give differing information about hydrology. 'Months flooded' is a simple measure of flooding duration, whereas 'mean seasonal depth' combines both flooding duration and water depth. 'C.V.' is an inverse index of hydroperiod, i.e. the smaller the coefficient of variation around mean depth, the more stable the level of flooding over the season and thus the longer the hydroperiod (and the deeper the bay). Of the 3 measures, C.V. provided the strongest correlations with the ordinations of vegetation.

TABLE B1. Matrix of Pearson correlations ( $r$ ) for hydrologic measures of SRS bays in the years 1995 and 1996. For all correlations, $n=34$ and $\mathrm{P} \leq 0.01$.

\begin{tabular}{lccccc}
\hline & $\begin{array}{c}\text { mean } \\
\text { depth 95 }\end{array}$ & C.V.95 & $\begin{array}{c}\text { months } \\
\text { flooded 95 }\end{array}$ & $\begin{array}{c}\text { mean } \\
\text { depth 96 }\end{array}$ & C.V.96 \\
\cline { 2 - 6 } & & & & & \\
C.V. 95 & -0.66 & - & & & \\
months flooded 95 & 0.58 & -0.97 & - & & \\
mean depth 96 & 0.92 & -0.52 & 0.44 & - & \\
C.V. 96 & -0.72 & 0.74 & -0.72 & -0.76 & - \\
months flooded 96 & 0.67 & -0.69 & 0.66 & 0.73 & -0.98 \\
\hline
\end{tabular}


Although mean depth and C.V. may be expected to have some correlation mathematically, there is also some independence in their relationship that suggests several hydrologic patterns among bays (Fig. B1). Of bays which maintain relatively stable water levels (C.V. $\leq 0.5)$, some are deeply-flooded (mean depth $\geq \mathrm{ca} .1 \mathrm{~m}$ ) and some are shallowly-flooded (mean depth = ca. $0.5 \mathrm{~m}$ ). Other bays dry down seasonally, usually by early summer, and thus have high C.V. values (C.V. $\geq 0.8$ ). This general pattern was exaggerated during a dry year (1996).

FIGURE B1. Relationship between mean seasonal water depth and the coefficient of variation of depth for SRS bays in 1995 (wet year) and 1996 (dry year).
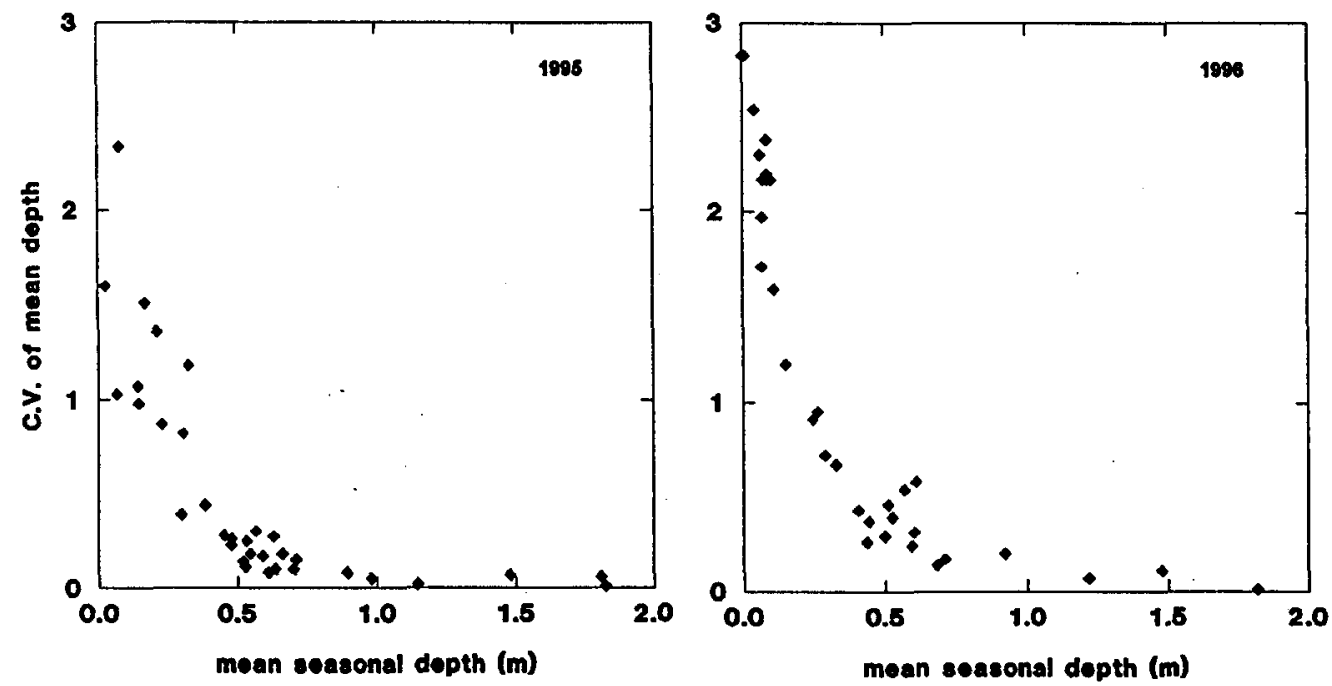

When 4 measures (mean depth and C.V. in 1995, mean depth and C.V. in 1996) were analyzed by UPGMA cluster analysis, bays assorted into 5 groups that could be ranked for 'average' hydrologic behavior over a wet year and a dry year : $1=$ large bays with deep and continuous flooding in both years, 2 = bays with shallow and continuous flooding in both years, 3 = bays shallowly-flooded in 1995 but drying by late summer in 1996, 4 = bays shallowly-flooded in 1995 but drying by early summer in 1996, and 5 = bays drying by early summer of both years.

Landscape distribution of the 5 hydrologic groups (Table B2) suggested that: a) "Sandhills" bays have a range of hydrologies; b) bays in the "Coastal Plain" uplands are more likely to have shorter hydroperiods; and c) Terrace bays tend to have longer hydroperiods ( $\chi^{2}$ test not sig.).

TABLE B2. Distribution of hydrologic group membership (based on cluster analysis) of bays in different soil/landform areas.

\begin{tabular}{lcccc}
\hline $\begin{array}{l}\text { hydrologic } \\
\text { group }\end{array}$ & \multicolumn{3}{c}{ no. of bays in each hydrologic group } \\
\cline { 4 - 5 } 1 & & Sandhills & Coastal Plain & Terrace \\
2 & 1 & 2 & 1 \\
3 & 3 & 1 & 7 \\
4 & 2 & 1 & 1 \\
5 & 3 & 1 & 1 \\
& 2 & 5 & 2 \\
\hline
\end{tabular}


Chmielewski (1996) found that Terrace bays have a high likelihood of ground-water inputs, as do at least some bays in the 'Sandhills' areas of the Lower Three Runs and Salkehatchie River watersheds. In contrast, bays of the higher-elevation 'Coastal Plain' uplands ('Plateau' upland) are likely to be largely surface-water fed. Bays in the Coastal Plain uplands are more likely to have clayey soils (i.e. shallow depths to a less-permeable soil horizon) than bays elsewhere on the SRS; these shallow soils may promote short hydroperiods if no ground-water input occurs.

\section{Hydrologic index for off-SRS bays and for the regional dataset (all bays)}

Staff gage data were unavailable for bays outside the SRS, thus information on hydrology was limited to observations during 1-3 visits to each bay during July-August 1996 plus 1 visit in January 1997. We developed a derived hydroperiod index based on water levels during these visits and on hydrologic patterns identified for SRS bays in the same year. SRS bays were ranked according to 1996 mean water depth and assigned to one of 4 hydrologic patterns based on timing of water drawdown and re-flooding, as follows: $1=$ continuously flooded, $2=$ drying late (Aug-Oct) or drying earlier with sporadic re-flooding, $3=$ drying early (May-June) and not re-flooding until winter, and $4=$ extremely dry except for minimal early flooding. For SRS bays, the index corresponded well to the quantitative measures for those bays (Table B3), which suggests it to be a useful indicator of relative hydroperiod.

TABLE B3. Pearson correlation coefficients between the hydrologic index and hydrologic measures for SRS bays. For all tests, $n=34$ and $\mathrm{P}<0.001$.

hydrologic measure:

hydroperiod index

mean seasonal depth 1996

C.V. 1996

0.96

months flooded 1996

$-0.96$

Each bay outside the SRS was assigned to one of the 4 values for the hydrologic index according to the observations available from the summer visits and according to the estimated likelihood of bays drying later in the year (based, in part, on landowner comments).

\section{Summary}

Overall, the analyses suggested that crude but informative characterizations of bay hydrology can be obtained from minimal information on the timing of bay drawdowns during 'normal' rainfall conditions. Some bays typically dry by late May to early June, some do not dry until August or September, and others remain either shallowly- or deeply-flooded throughout the year. During extreme drought periods (e.g. the decade of the 1980's), these patterns will become less distinct, and nearly all bays may dry seasonally. Hydrology is likely also affected by vegetation or land uses surrounding a bay; thus activities such as clearcutting may significantly change hydrologic pattern (there is evidence of this for one SRS bay whose perimeter was cleared late in 1995). The effects of managing forested buffer zones adjacent to bays warrant further research. 
APPENDIX C. Characterization of Carolina bay soils.

\section{Soil sampling}

Soil series and soil profile features from standard 60-inch deep cores were described by Robert Eppinette of the NRCS. On the SRS, extensive data were collected to characterize the soil catenas across the transition from upland to wetland interior. For each SRS bay, a linear transect of soil profiles was arrayed as follows: a) one or more "upland" cores located at least $120 \mathrm{ft}$ outward from the bay "edge" (defined as the location where depth to soil gleying is greater than $10 \mathrm{in}$.), b) three closely-spaced "transitional" cores placed $20 \mathrm{ft}$ apart across the bay edge, and c) a series of "interior" cores spaced at 100-ft intervals (in large bays, 200-ft) from the innermost transitional core to the bay center. A simpler dataset was collected for the bays in the surrounding region. For each bay outside of the SRS, one "upland" profile and two "interior" profiles (spaced 100' apart at, and adjacent to, the bay center) were described. For all bays in the study, the central core of each transect was subsampled at three depths $(0-6,24-30$, and 54-60 in.), and all subsamples were analyzed for $\mathrm{pH}$ and total concentrations of plant macronutrients (N, P, K, Ca, Mg). Particle-size distribution and organic matter content were determined for a subset of cores.

The complete soils dataset is being analyzed by Dr. Carl Trettin of the USFS Center for Forested Wetlands Research. Many bays appear to have a uniform interior soil type, but large bays may have interior catenas.

\section{Bay soil types}

For our study, we used the data from the interior cores to assign a 'typical' (predominant) soil type for each bay and to extract quantitative measures for use in the gradient analyses. Soils of bay interiors were generally of two classes, generalized here as 'clayey' and 'sandy':

- clayey soils : These soils have horizons of clay or sandy clay starting at 10-12 in. Nearly all clayey soils found in the bays were in the Rembert series (cf. App. A); these soils typically have a clayey "lens" between ca. 12-30 in. overlying coarser-textured loamy sand or sandy clay loam. This clay lens could promote ponding of water and generate a temporary perched water table. Many of the bays which had Rembert soils also had ditches running through their interiors; we speculate that such ditching could have served to penetrate the clay lens and thus increase downward water drainage.

- sandy soils: These soils lack a clayey lens or shallow clayey subsoil. Most sandy soils in bays were in the Ogeechee series ('typic' soil subgroup), which are sandy to $\leq 24$ in over a finer-textured sandy clay loam subsoil. Some bays had much deeper sands to 24-40 in. ('arenic' subgroup) or greater ('grossarenic' subgroup) (Williman, Pelham, or Plummer series). In a few large bays, high water levels prevented sampling of the bay center (cf. App. A), so it is possible that clayey soils outcrop in the interiors of these bays. 
Particle-size analysis (Table C1) confirmed these soil types as identified in the field. 'Sandy' soils had significantly higher sand content, both in their topsoils and especially in their subsoils, which distinguishes them from 'clayey' soil types. Given these properties and the availability of high-quality soil profile descriptions, we used the depth of sand over clay (i.e. depth to a horizon of clay or sandy clay texture) as a quantitative measure of soil type. Mean sand depth over clay, averaged over all interior profiles, was used to characterize the soil type of each bay. In this study, 'clayey' soils had a mean sand depth of 13 in., and sandy soils had a mean depth of 43 in. Within the sandy group, soils of 'typic' subgroups averaged 39 in. sand depth, and soils of 'arenic' or 'grossarenic' subgroups averaged 50 in. sand.

\section{Bay soil chemistry}

Analysis of soil chemistry generally corroborated the differences in physical soil properties between the two soil classes (Table $\mathrm{C} 1$ ). The topsoils of clayey and sandy soils did not differ significantly in $\mathrm{pH}$ or in macronutrient concentrations, although the trend was for somewhat higher values for clayey soils. However, whereas vegetation may strongly affect topsoil chemistry, subsoil chemistry may better reflect inherent soil properties such as parent material. Compared to clayey soils, the subsoil layer of sandy soils had significantly lower values for all macronutrients except phosphorus and was less acidic. Total nitrogen was highly correlated with soil organic matter both in the topsoil layer (Spearman $r_{s}=0.94, n=23, \mathrm{P}<0.001$ ) and also in the subsoil layer $\left(\mathrm{r}_{\mathrm{s}}=0.64, n=19, \mathrm{P}<0.01\right)$. Thus in general, the clayey soils may be somewhat more fertile (and less droughty when drained) than the sandier soils.

\section{Bay soils in the landscape}

Bay soil types reflect their generalized landscape setting, in that there were significant differences across soil/landform areas in the distribution of bay soil types. In the "Coastal Plain Uplands", $82 \%$ of bays had clayey soils, compared to $41 \%$ in the "Sandhills" uplands and $59 \%$ on "Terrace" landforms ( $\chi^{2}=6.9, \mathrm{df}=2, \mathrm{P}<0.05$ for the regional sample of 57 bays).

In general, bay hydrology was not predictable from bay soil type (i.e. 'clayey' vs. 'sandy' soils did not differ for any hydrologic measures). However, because bay hydrologies tend to differ across the landscape (cf. App. B), there was interaction between bay soils and soil/landform area. In the Coastal Plain uplands, bays with clayey soils had shorter hydroperiods than bays with sandy soils $(F=3.6 ; \mathrm{df}=1,20 ; \mathrm{P}<0.05)$ whereas clayey and sandy soils had similar hydrologies both in the Sandhills uplands and on the Terrace landform. This may reflect groundwater inputs that contribute to more stable hydroperiods in bays of the latter two areas (cf. Chmielewski 1996).

\section{Summary}

Bays differ substantially in soil types; these differences reflect the landscape setting and have at least indirect impacts on hydrology and on vegetation. Physical descriptions of soils in the field provide significant information about soil properties and chemistry and should be utilized more widely in ecological assessments. In this study, soil type showed stronger relationships with vegetation pattern than did the finer-scale data on soil chemistry. 
TABLE C1. Characteristics of principal soil types found in Carolina bays of NW South Carolina. Data are means and s.e. (in parentheses), based on one composited soil sample per bay, taken at or near the bay center ( $n=$ no. of samples). Outlier values were omitted in calculating some means. Soil texture data are from SRS bays; soil chemistry data are from all bays. ANOVA P : significance of F-test for difference between soil types (clayey vs. sandy); $\mathrm{Pt}=$ topsoil, $\mathrm{Ps}=$ subsoil; tests for chemistry performed on log-transformed values. $+0.05<P<0.10, * P<0.05,{ }^{* *} P<0.01,{ }^{* * * P}<0.001$

\begin{tabular}{cccccc}
\multicolumn{2}{c}{ Clayey soils } & \multicolumn{2}{c}{ Sandy soils } & \multicolumn{2}{c}{ ANOVA P } \\
\cline { 5 - 6 } & Sopsoil [0-6"] Subsoil [24-30"] & Topsoil [0-6"] & Subsoil [24-30"] & Pt & Ps
\end{tabular}

Texture:

$\%$ sand

$45(4)$

$26(2)$

$29(3)$

16

$n$

$\%$ silt

$\%$ clay

$\S$ Chemistry:

$\mathrm{N}(\%)$
$\mathrm{P}$
$\mathrm{K}$
$\mathrm{Ca}$
$\mathrm{Mg}$
$\mathrm{pH}$

$n$

$0.43(0.07)$

$10.6(1.1)$

$47.2(4.2)$

259.8 (42.5)

$58.2(8.0)$

$4.63(0.05)$

35-36
$56(4)$

$10(2)$

34 (3)

16

$$
\begin{aligned}
& 59(3) \\
& 19(2) \\
& 21(2)
\end{aligned}
$$

17

$0.04(0.004)$
$8.0(1.5)$
$37.0(4.6)$
$343.6(58.6)$
$81.4(8.9)$
$4.81(0.04)$
34

$0.24(0.03)$

$9.7(0.9)$

39.8 (4.8)

$168.8(23.4)$

$28.3(3.7)$

$4.64(0.06)$

18-19
75 (4)

$6(2)$

$19(3)$

15

'clayey' soils are in the 'clayey, kaolinitic' soil family and include the Rembert, Coxville, and McColl series

'sandy' soils are in the 'siliceous' soil families and include typic (Ogeechee series), arenic (Pelham and Williman series), and grossarenic (Plummer series) soil subgroups

$\S$ values for $\mathrm{P}, \mathrm{K}, \mathrm{Ca}, \mathrm{Mg}$ are reported in $\mathrm{lb} / \mathrm{ac}$ ( approx. $=2 \mathrm{xpm}$ ) 
APPENDIX D. Relevant environmental and historic variables for 57 Carolina bays in the study.

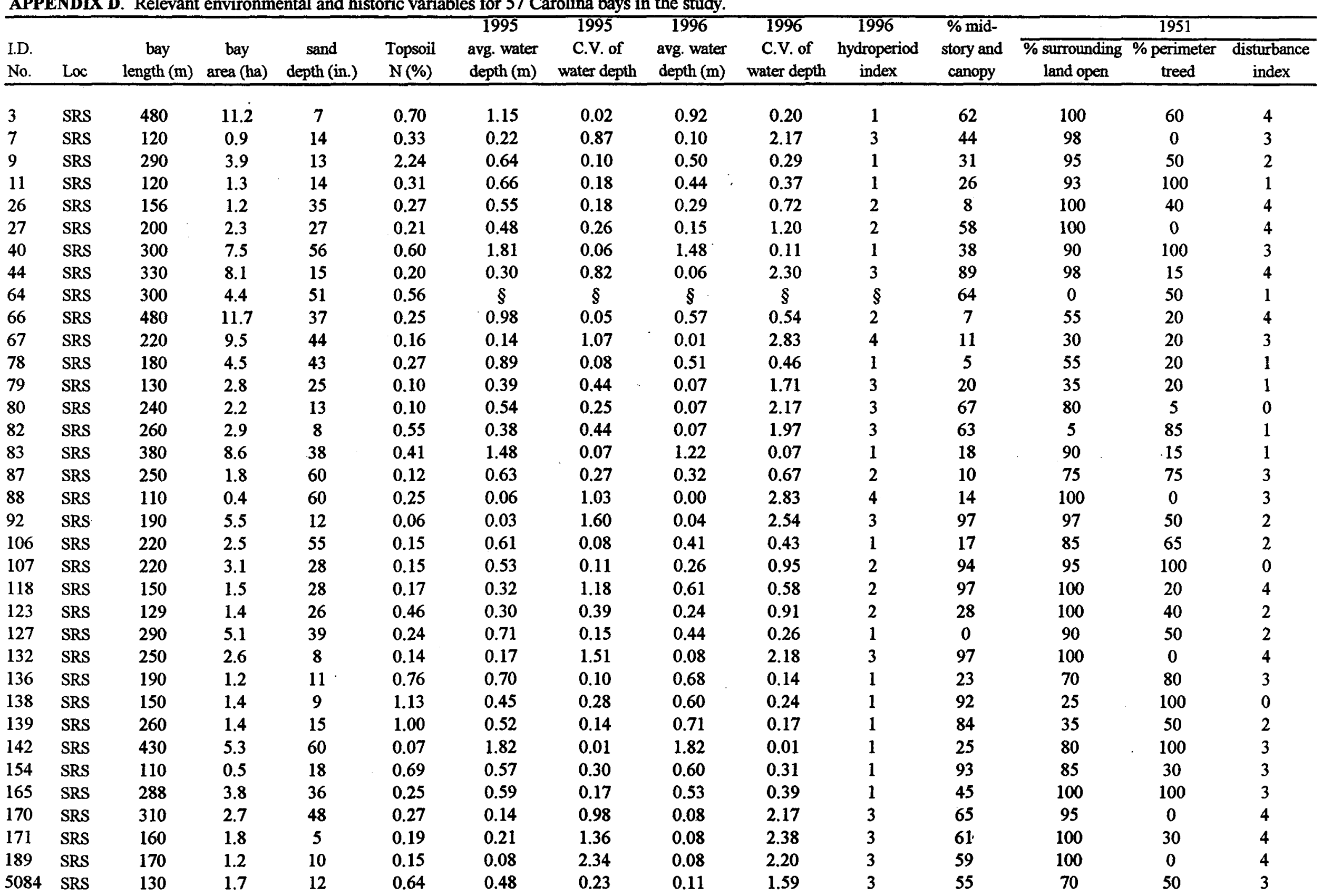


APPENDIX D. (cont.)

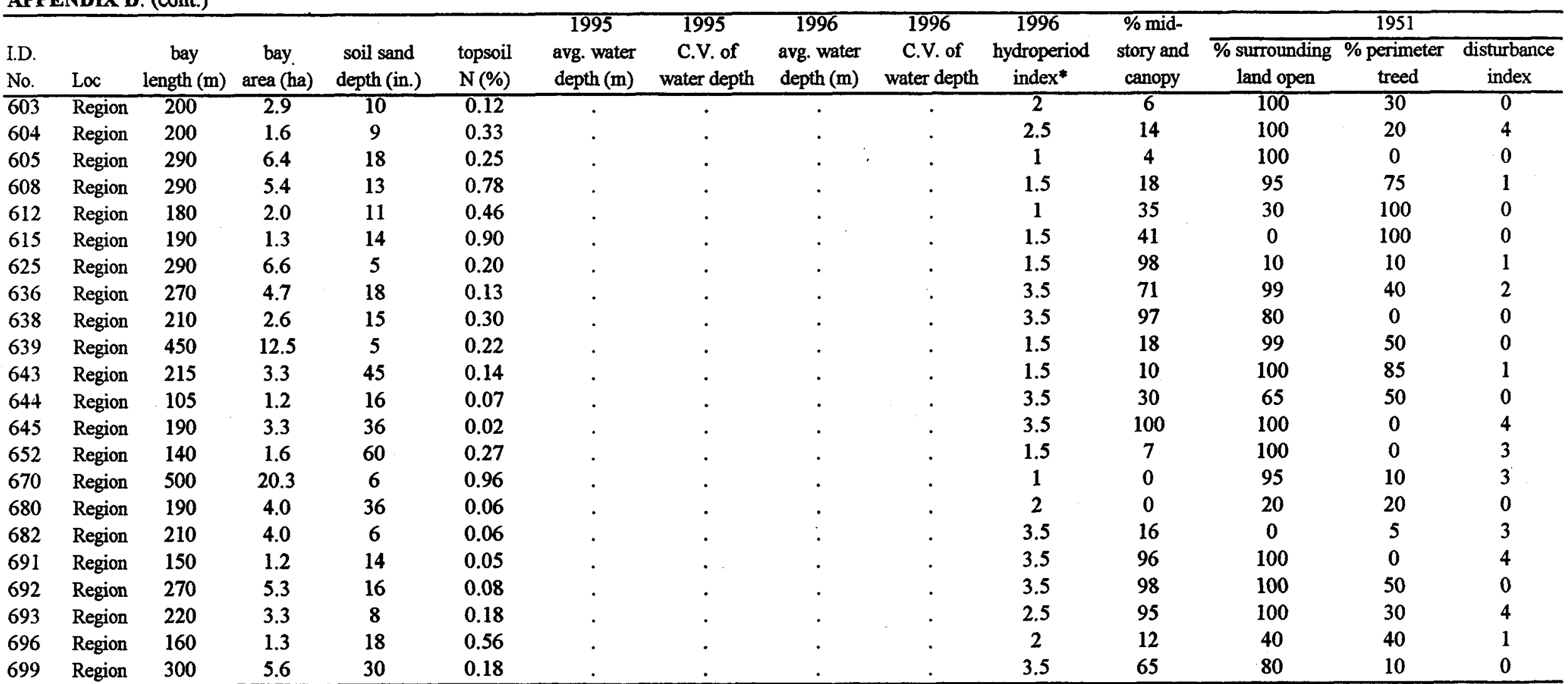

$\S$ bay had anomalous hydrologic data and was therefore omitted from analyses of hydrology

* represents the average of two possible estimates of hydrologic pattern 
APPENDIX E. Endangered, threatened, and sensitive species identified in the survey bays. Legal status: $\mathrm{FE}=$ federally endangered; $\mathrm{RC}=$ regional concern; $\mathrm{SC}=$ state concern. The Nature Conservancy Rank: S1 = critically imperiled; S2 = imperiled; S3 = rare or uncommon; S? = status unknown.

\begin{tabular}{|c|c|c|c|c|c|}
\hline Species & $\begin{array}{c}\text { Bays of occurrence } \\
\text { (SRS \& off-SRS) }\end{array}$ & $\begin{array}{c}\text { Associated } \\
\text { community- } \\
\text { types }^{3}\end{array}$ & $\begin{array}{l}\text { Legal } \\
\text { status }\end{array}$ & $\begin{array}{l}\text { TNC Rank } \\
\text { for South } \\
\text { Carolina }\end{array}$ & $\begin{array}{l}\text { Known } \\
\text { from } \\
\text { SRS? }\end{array}$ \\
\hline Coreopsis rosea & $\begin{array}{l}\text { SRS: - } \\
\text { Off: } 603,604,670\end{array}$ & hm, pd & $\mathrm{RC}$ & S2 & $\mathrm{Y}^{1}$ \\
\hline Croton elliottii & $\begin{array}{l}\text { SRS: } 118,132,171 \\
\text { Off: } 682\end{array}$ & $\mathrm{mf}, \mathrm{hm}$ & $\mathrm{SC}$ & S? & - \\
\hline Eleocharis robbinsii & $\begin{array}{l}\text { SRS: } 3,66,78,82,83,87 \\
\text { Off: } 608,670\end{array}$ & $\mathrm{gr}, \mathrm{hm}, \mathrm{pd}$ & SC & S? & - \\
\hline Eriocaulon texense ${ }^{\mathrm{t}}$ & $\begin{array}{l}\text { SRS: - } \\
\text { Off: } 636\end{array}$ & $\mathrm{cw}$ & $\mathrm{SC}$ & S? & $\mathrm{N}$ \\
\hline Ilex amelanchier & $\begin{array}{l}\text { SRS: - } \\
\text { Off: } 636\end{array}$ & cw & $\mathrm{SC}$ & S3 & $\mathrm{N}$ \\
\hline Ludwigia spathulata & $\begin{array}{l}\text { SRS: } 44^{\mathrm{t}}, 106 \\
\text { Off: } 680\end{array}$ & $h m, \mathrm{mf}^{\mathrm{t}}$ & SC & S? & - \\
\hline Oxypolis canbyi & $\begin{array}{l}\text { SRS: - } \\
\text { Off: } 699\end{array}$ & cw & $\mathrm{FE}$ & S1 & $\mathrm{Y}^{2}$ \\
\hline Rhexia aristosa & $\begin{array}{l}\text { SRS: - } \\
\text { Off: } 636,699\end{array}$ & cw & $\mathrm{SC}$ & S2 & $Y^{1}$ \\
\hline Rhynchospora inundata & $\begin{array}{l}\text { SRS: } 9 \\
\text { Off: } 639,696\end{array}$ & gr, pd & SC & S? & - \\
\hline Rorippa sessiliflora & $\begin{array}{l}\text { SRS: - } \\
\text { Off: } 691\end{array}$ & $\mathrm{mf}$ & SC & $S ?$ & $Y^{1}$ \\
\hline Sagittaria isoetiformis & $\begin{array}{l}\text { SRS: } 66,67,80,106 \\
\text { Off: - }\end{array}$ & hm, wf & SC & S2 & - \\
\hline Scirpus etuberculatus & $\begin{array}{l}\text { SRS: - } \\
\text { Off: } 608\end{array}$ & pd & SC & S? & $\mathrm{Y}^{2}$ \\
\hline Stillingia aquatica & $\begin{array}{l}\text { SRS: - } \\
\text { Off: } 615\end{array}$ & pd & SC & S1 & $Y^{2}$ \\
\hline Utricularia floridana & $\begin{array}{l}\text { SRS: }- \\
\text { Off: } 625,670\end{array}$ & wf, pd & SC & S1 & $Y^{1}$ \\
\hline
\end{tabular}

\footnotetext{
${ }^{1}$ Knox and Sharitz $1990 ;{ }^{2}$ Workman \& McLeod $1990 ;{ }^{3}$ of the survey bays ; ${ }^{t}$ tentative, or unconfirmed identification
} 
APPENDIX F. Sample information provided to cooperating private landowners and managers.

To carry out the bay survey outside of the SRS in1996, it was necessary to obtain permission for access to private land holdings. We found that managers and some owners cooperated freely and with great interest, whereas other owners were initially hesitant. We believe that access was made easier by the fact that we were not directly affiliated with a state or federal agency, but instead were university-related investigators with general research as an objective. In some cases, owners provided access contingent upon the agreement that the specific location would not be made public without their knowledge or permission. This assurance was sufficient to allay their potential concerns in all but one instance.

We made contacts by telephone and followed up with a confirming letter thanking them for their assistance. In return for permission to survey, we provided the following to each private landowner or manager after we completed the study:

1) a two-page general summary of our research findings (App. F1)

2) a two-page report of the specific findings for their site (App. F2)

Examples of these are appended here. We felt that the small additional effort to generate these "reports" was justified by the potential benefits of increased conservation awareness and perhaps, eventual conservation action by some of these owners in the future. 
APP. F1. Research Summary provided to private landowners who permitted access to their properties.

\section{Research Summary}

\section{Carolina Bays: a special kind of wetland}

If you happen to have a Carolina bay on your property, you have probably heard a great deal about them. These distinctive wetlands are found only in the southeastern United States. As wetlands, they have important ecological functions as a water resource and as wildlife habitat. Carolina bays have attracted special interest because of their diversity of plant (and animal) life. Bays have a variety of plant communities, and even a single bay contains many species. For example, if you decided to walk into a Carolina bay, you might start under water oak or tupelo trees on the edge, and wander (with some effort) through a ring of buttonbush or maidencane grass before wading into a pond of water lily, pickerel-weed, and bladderworts. On the way, you might be lucky enough to spot a rare plant species such as pink tickseed or awned meadow beauty.

Bays occur on the Coastal Plain from north Florida to New Jersey, but they are most common in the Carolinas (hence the name!). Because bays were often ditched, drained, and converted to agricultural uses, much of this distinctive habitat has been lost. Two South Carolina biologists, S. Bennett and J. Nelson, estimated that there were perhaps 4000 bays in the state; yet only 400-500 have been unaltered, and even fewer are in good condition.

Many intact bays are located on public lands and thus could be protected or managed for conservation. As a guide to such efforts, we conducted our study of bays in the Upper Coastal Plain region of northwestern South Carolina to provide a better understanding of factors that may influence the vegetation of these bays.

\section{Results: general patterns and plant community types}

Patterns: Our research identified four key patterns relating the type of vegetation in bays to other features such as size, soil type, and degree of flooding. These patterns may provide useful guidelines for conserving or restoring specific types of plant communities.

- In the Upper Coastal Plain, large bays tend to be deep-water ponds or grassy bays.

- Bays in the Upper Coastal Plain have mineral soils which consist of a sandy or loamy layer over a denser subsoil of more clayey material. The sandy layer varies in thickness. An interesting finding was that bays with deep, sandy soils are less likely to support woodlands and more likely to support an uncommon "herbaceous" plant community.

- Bays that are continuously flooded have either, or both, of two vegetation types. Where flooding is deep, there is aquatic vegetation (plants that grow underwater or plants with floating leaves). If flooding is shallow, there is usually some mixture of swamp tupelo and/or pond cypress woodland.

- Certain bay vegetation types may be associated with low-lying areas, such as river terraces, that are in greater contact with the groundwater table. 
Plant community types: From our study of more than 50 bays, we identified five main types of plant communities in the Upper Coastal Plain region: two are forested types and three are "open" communities. Each community can be recognized by certain characteristic plant species that are particularly abundant in that type.

\section{Forested communities}

- Wet forest. Characteristic species: swamp tupelo. Tupelo is a widespread tree in bays and is found with many other species such as buttonbush, cypress, sedges, and cutgrass. "Wet forest" bays are dominated by tupelo trees and tend to be shallowly flooded for most of the year. Bennett and Nelson referred to this type as "non-alluvial (non-river) swamp", such bays are also locally called "gum-ponds". Pond-cypress is often found with swamp tupelo in bays that are shallowly flooded for most of the year. Valued for its wood, cypress was frequently logged out of bays; this history makes it difficult to determine if there is one community type or several. Bennett and Nelson described two pond-cypress types, but we did not find enough examples to verify this.

- Mesic forest. Characteristic species: sweetgum. Other common species include red maple and woody vines such as catbriers. Mesic ("moderately-wet") forest is found in bays that have very short flooding periods and thus are somewhat drier. Bennett and Nelson referred to this community as a "regrowth" type, as it is found in many bays that had formerly been drained for agricultural use and then abandoned..

\section{Open (non-forested) communities}

- Sedge meadow. Characteristic species: Walter's sedge. This is a distinct type not identified by Bennett and Nelson, perhaps because it is uncommon. Bays of this type seem to occur on old river terraces, which are areas with a high water table. These sedge meadows often have swamp tupelo on their outer margins and thus may be related to the wet forest type.

- Herbaceous meadow. Characteristic species: cutgrass and rushes. These are generally smaller bays that seem to be associated with very sandy soils. They tend to dry down in the summer, and in dry years they may be invaded by pine trees. Bennett and Nelson referred to these as "depression meadows" and suggested that they are fairly uncommon in South Carolina. These meadow communities can be quite diverse and often contain rare plant species.

- Aquatic or grassy ponds. Characteristic species: water lily and/or maidencane grass. This most resembles the "open-water lake" type described by Bennett and Nelson. These are usually larger bays that are flooded to depths of 3-4 ft throughout the year. There may be a central deeper area of open water surrounded by a ring of grassy or meadow vegetation. 
APP. F2. Individual bay report provided to each private landowner or cooperating land manager who permitted access to their properties.

\section{Summary of Information for}

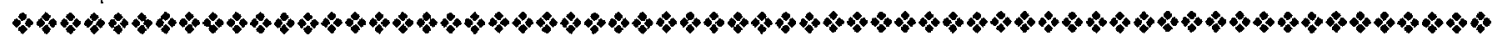

\section{Plant Community:}

Your bay is a herbaceous meadow with a remarkably distinct pattern of zonation. Although there is a central pool with aquatic species such as heartleaf and bladderworts, the most abundant species are cut grass and round-pod water-primrose. The cut grass forms the first grassy margin around the pool and the water-primrose is the next, almost bushy, ring of plants. The outermost zone before the trees is annual panic grass. This pattern probably develops as water levels fall over the summer months.

Species of note: Panic grass and devil's beggar-ticks, which are abundant among the water-primrose, together comprise one of the largest representations of annual species found in our survey. Bead-grass, another annual, is also of special interest. Once thought to be quite rare, it is now believed to have been under-reported because it appears only during droughty conditions in herbaceous meadows or cypress bays.

\section{Soils:}

In general, there is a gradual transition of soil features from upland areas into low-lying areas such as bays. Clayey layers that cause the ponding of water may be quite deep in the upland, but will be nearer to the surface in the wetland.

An Albany soil was identified near the upland margin of the bay. This infertile Coastal Plains soil is somewhat poorly drained and represents a transitional soil between very sandy uplands and more saturated wetland soils. Soil scientists categorize this soil as grossarenic, meaning that it is sandy to depths greater than $4 \mathrm{ft}$. over a finer-textured subsoil of sandy clay loam. The Albany subsoil has a mottled coloration, which is evidence of water saturation below the surface. In the bay itself, both Plummer and Pelham soils were identified. Soil scientists categorize these two "hydric" (wetland) soils as arenic, meaning that they have $2-4 \mathrm{ft}$. of sand over a finer-textured subsoil of sandy clay loam and sandy clay. The Plummer and Pelham soil layers have a mottled coloration, which reflects the water-saturated conditions in the bay. Our studies have suggested that the "herbaceous meadow" type of plant community, which often has unusual or rare plant species, may be associated with very sandy soils such as these two types. 
Species List

Survey Date: July 24, 1996

\begin{tabular}{ll} 
Common name(s) & Scientific name \\
\hline Red maple & Acer rubrum \\
Devil's beggar-ticks & Bidens frondosa \\
False nettle & Boehmeria cylindrica \\
Trumpet-creeper, Trumpet vine & Campsis radicans \\
Sedge & Carex tribuloides \\
Buttonbush & Cephalanthus occidentalis \\
Virginia buttonweed & Diodia virginiana \\
Persimmon & Diospyros virginiana \\
Least spike-rush & Eleocharis acicularis \\
Three-ribbed spike-rush & Eleocharis tricostata \\
American holly & Ilex opaca \\
Cut grass & Leersia hexandra \\
Sweet-gum & Liquidambar styraciflua \\
Water willow & Ludwigia leptocarpa \\
Round-pod water-primrose & Ludwigia sphaerocarpa \\
Heartleaf & Nymphoides cordata \\
Swamp blackgum, Swamp tupelo & Nyssa sylvatica variety biflora \\
Blackgum, Black tupelo & Nyssa sylvatica variety sylvatica \\
Maiden-cane & Panicum hemitomon \\
Annual panic grass & Panicum verrucosum \\
Pine (loblolly/slash) & Pinus species \\
False water-pepper, Smartweed & Polygonum hydropiperoides \\
Pondweed, Fishweed & Potamogeton species \\
Bead-grass & Paspalum dissectum \\
Coastal plain mermaid-weed & Proserpinaca pectinata \\
Willow oak & Quercus phellos \\
Poison ivy & Rhus radicans \\
Black willow & Salix nigra \\
Bulrush, Wool grass & Scirpus cyperinus \\
Greenbrier, Catbrier & Smilax rotundifolia \\
Greenbrier, Catbrier & Smilax species \\
Bladderwort & Utricularia biflora \\
& \\
\hline
\end{tabular}

